\title{
Insurance, Systemic Risk and the Financial Crisis
}

\author{
Faisal Baluch $^{\mathrm{a}}$, Stanley Mutenga ${ }^{\mathrm{b}}$ and Chris Parsons ${ }^{\mathrm{b}}$ \\ ${ }^{a}$ Commerzbank, 60 Grace Church Street, London EC3V OHR, U.K. \\ ${ }^{\mathrm{b}}$ Sir John Cass Business School, 106 Bunhill Row, London, EC1Y 8TZ, U.K.
}

In this paper we assess the impact of the financial crisis on insurance markets and the role of the insurance industry in the crisis itself. We examine some previous "insurance crises" and consider the effect of the crisis on insurance risk - the liabilities arising from contracts that insurers underwrite. We then analyse the effects of the crisis on the performance of insurers in different markets and assess the extent of systemic risk in insurance. We conclude that, while systemic risk remains lower in insurance than in the banking sector, it is not negligible and has grown in recent years, partly as a consequence of insurers' increasing links with banks and their recent focus on non-(traditional) insurance activities, including structured finance. We conclude by considering the structural changes in the insurance industry that are likely to result from the crisis, including possible effects on "bancassurance" activity, and offer some thoughts on changes in the regulation of insurance markets that might ensue.

The Geneva Papers (2011) 36, 126-163. doi:10.1057/gpp.2010.40

Keywords: insurance; systemic risk; financial crisis; credit risk

\section{Introduction}

Historically, there has been a distinct separation between insurance, banking and other financial markets in most countries, so that events in one sphere usually had little effect on the other. However, in recent years the barriers between insurers, banks and other financial firms have been partly dismantled, resulting in much closer affiliations between them and more linkages and overlaps in their activities. This phenomenon, which is partly, but not wholly, encapsulated in the term "bancassurance", began at an earlier date in Europe than in the United States, and earlier still than in major Asian markets such as Japan and Korea, where legislation separating banks from insurers has existed until very recently. However, given that the barriers referred to above have been at least partly removed in many countries, we may well ask whether the current financial crisis, which began mainly in the banking sector, has spilled over into an "insurance crisis", and whether this, in turn, has made the whole financial crisis worse. As we shall see, the financial crisis has indeed impacted on insurance markets to a significant degree and events in insurance markets have, in turn, affected the way in which the crisis has developed. However, the impact of the crisis on insurers has been very uneven: in some parts of the insurance market the effects have been relatively muted, in other sectors they have been severe.

Our paper is structured in five parts. We begin by briefly examining some previous insurance "crises" and then go on to consider the effect of the current upheaval on 
insurance risk; that is, the effect of the crisis on the underwriting activities of insurers and the liabilities they assume thereby. Lines of insurance that have been particularly affected are identified and discussed. We then move on to consider the effects of the crisis on the performance of insurers in different market sectors and in different parts of the world, comparing their performance with that of banks at various points. We then move on to consider the general question of systemic risk in the field of insurance, discuss the main sources of such risk and assess the extent to which, if any, it has expanded. In our conclusion, we summarise the effects of the crisis on insurance markets and consider the structural changes that we are likely to see as a result.

\section{Previous insurance "crises"}

Has there ever been an "insurance crisis" that parallels the "credit crunch" and connected events in the banking world? Certainly, there have been a number of upheavals in insurance markets that some, at least, have described as "crises": that is, periods characterised by the failure (or near failure) of one or a number of insurance firms, reduction in the supply of insurance and significant disruption of economic activity. A notable example is the 1984-1986 U.S. "liability insurance crisis", during which U.S. property/casualty insurers made huge losses and insolvencies became commonplace. As a result, insurance capacity dwindled alarmingly as insurers (and reinsurers) attempted to restore profitability. The causes of this "crisis" are still disputed, but reported effects included, inter alia, the closure of some children's playgrounds when insurance for them became unobtainable and rocketing premiums for medical malpractice insurance, which allegedly led to rise in "defensive medicine" and diverted physicians away from those branches or medicine where premiums were most punitive.

The near collapse of the 300-year-old Lloyd's insurance market in the early 1990s provides another interesting example of a major upheaval in the world of insurance. Injudicious underwriting, an exceptional number of major catastrophes in a short space of time and internal management problems caused Lloyd's collectively to make huge losses over the period in question (around GB£8 billion between 1988 and 1992), bankrupting many Underwriting Members and bringing Lloyd's close to insolvency. In the end Lloyd's did not fail. Rather, it recovered, restructured and reinvented itself, regaining its place in the world insurance market for large, unusual, extra-hazardous and internationally traded risks. However, had it occurred, the failure of Lloyd's would have dealt a hard blow to the world insurance system by curtailing the supply of cover for the sorts of risks described above, which would have caused significant economic disruption.

At this point, it is worth remarking an interesting parallel between one facet of Lloyd's problems and a key source of the current financial crisis. This was the London Market Excess (LMX) reinsurance (or retrocession) "spiral" that developed at Lloyd's in the early 1990s. Retrocession (the further transfer of risk by a reinsurer to another

\footnotetext{
${ }^{1}$ They include, among other things, collusion by insurers, cyclical behaviour, abrupt changes in reinsurance market conditions and unchecked expansion of tort liability, or some combination of these.
} 
(re)insurer) enables risks to be spread more widely, but also creates a credit risk for the reinsurer concerned that could, in turn, impact upon cedants from which the reinsurer itself has accepted risks. The LMX spiral developed from the continued retrocession by Lloyd's syndicates of much of their business, so that many syndicates underwrote again the very risks they had transferred, sometimes without knowing it. Commission was shaved off the premiums each time the risk was passed on, threatening to leave insufficient capital to pay for losses, and therefore contributing to the overall Lloyd's crisis. This situation, with multiple participants parcelling up and selling on risks to the point where the players lose track of their own and others' exposures-effectively magnifying risk rather than managing it - is obviously echoed in the frenetic trading of credit derivatives that played a major part in the current banking crisis. In fact, reinsurance has been identified as one part of the insurance market where there is, at least potentially, some systemic risk. This is discussed later.

In addition to the U.S. liability crises and the Lloyd's near-debacle, there have been many other upheavals, sometimes affecting one line of insurance only (such as the product liability crisis of 1976-1977, and the shortage in terrorism cover following the events of 11 September 2001). However, these "crises" have been relatively short in duration and, more important for the purpose of this study, mostly local in terms of their impact. ${ }^{2}$ Again, we should not confuse a sharp rise in insurance prices with a failure of supply. The cyclical nature of insurance is such that hard markets occur quite regularly, but it is rare indeed for any common form of insurance to be unobtainable at any price. We should also bear in mind that the direct economic disruption caused by insurance "crises" such as those described is unlikely to be as severe as the devastation that can flow from the drying-up of credit markets. The latter, we know well, can severely damage the real economy and trigger a worldwide recession. By contrast, even a massive rise in the cost of insurance is unlikely in itself to cause much damage to the real economy. This is so because the cost of insurance, relative to other costs, is quite small for most businesses. In any event, the fact that there has never been a major worldwide "insurance crunch" suggests that there are some fundamental differences between banking and insurance markets, with less risk of systemic failure in the case of the latter. Again, this is considered later in this paper.

All this does not mean that the insurance industry has proved immune to the effects of the current crisis, nor does it mean that insurance markets and mechanisms have played no part in the crisis itself. The insurance industry has been affected in a number of ways. As we shall see, some insurers have moved away from "traditional" insurance risks and started to assume financial (and especially credit-related) exposures that are much more prone to systemic risk, thus aligning their fortunes more closely with firms in the banking sector. This is discussed in the section "Systemic risk in banking and insurance". First we will consider how the financial crisis, and the deterioration in the risk environment that it has brought about, has affected the traditional underwriting activities of insurers.

\footnotetext{
${ }^{2}$ For example, there was no "liability insurance crisis" in Europe in the mid-1980s.
} 


\section{Effect of the crisis on insurance risk}

Non-life insurance claim levels tend to rise generally in an economic downturn. Almost inevitably, there will have been some increase in fraudulent or exaggerated claims during the recent recession and more claims for relatively trivial losses that would go unclaimed in better times. ${ }^{3}$ Demand for non-life insurance is relatively inelastic, because few substitutes for insurance exist and because some major lines (such as motor) are mandatory. However, a financial crisis and ensuing recession will inevitably reduce demand to some extent, forcing insurers to cut costs (e.g. by shedding staff) in order to maintain profitability. Confirming this, Swiss Re record an overall decline of 0.8 per cent in non-life premiums in 2008 as a consequence of fall in demand and softening rates, a sharper fall of 1.9 per cent in the industrialised countries being partly offset by growth in the emerging markets, which remained strong at 7.1 per cent compared to 2007 levels. Swiss Re note, however, that non-life insurance remained profitable, despite falling premiums. They expect non-life premiums to remain flat in 2009, as the economic downturn continues to curb demand, particularly in the commercial lines of business. ${ }^{4}$

In the case of life insurance, claim payments as such do not increase in a recession, but the cashing in of policies, and the drop in demand for new ones (particularly for saving plans and mortgage-linked products), is likely to be more severe, creating a greater imperative to cut costs. Swiss Re confirms that the global financial crisis has indeed hit life insurance premium growth in particular, with a decline of 3.5 per cent in global premiums in 2008, most of it relating to the second half of the year. They note: "Sales of unit-linked products and products linked to equity markets were severely impacted by falling stockmarkets in 2008, causing life insurance premiums in industrialised countries to drop by 5.3 per cent (US\$ 2.219 billion). Sales of non-linked savings products, such as fixed annuities and traditional life savings, continued to increase in many countries, but failed to offset the declines seen in the unit-linked business". "Strong growth in emerging markets was clearly not enough to reverse these trends.

Quite apart from these general effects, there are some specific lines of non-life insurance where the impact of the banking crisis is likely to be more direct and more intense. These are liability insurance and insurance that covers credit risk. We look at these next.

\section{Liability insurance}

Of course, in addition to insuring property and various forms of financial loss, non-life insurers also write liability (or casualty) insurance, covering losses that individuals or firms incur when they are sued for negligence or other legal wrongdoing. Banks, financial firms and their professional advisors (such as lawyers and accountants who operate in financial markets), real estate agents, mortgage brokers and the like are at risk of compensation claims by clients who believe themselves to be victims of

\footnotetext{
${ }^{3}$ These factors have undoubtedly contributed to the very sharp rise in motor and home insurance premiums in the United Kingdom in the last quarter of 2009. See Insurance Times, 28 January 2010, from www.insurancetimes.co.uk/story.asp? storycode $=382527$.

${ }^{4}$ Swiss Re (2009).
} 
130

negligence. Stakeholders (such as shareholders) in financial businesses who suffer loss as a consequence of mismanagement by the firms' own directors or senior management may also target the individuals concerned. The first of these risks is insured under Errors and Omissions insurance (E\&O) and the second under Directors' and Officers' insurance (D\&O). Leading insurers in these markets include AIG (which writes around 35 per cent of D\&O insurance by premium volume), Chubb (which writes around 15 per cent), XL and Lloyd's of London.

A major financial downturn always brings an increase in liability suits of this kind as firms and individuals look around for people to blame for their losses - the "dotcom" crash of 2000 being a recent episode that triggered such a spike in claims. Most business leaders in the United Kingdom believed, at least initially, that the current financial crisis would generate even more claims than the punctured dotcom bubble, ${ }^{5}$ and all insurers in this market anticipate a sharp rise. One analyst suggests that claims will reach US\$9.6 billion, comprising US\$5.9 billion for D\&O and US\$3.7 billion for E\&O ${ }^{6}$ others suggest upward of US\$12 billion for D\&O alone. ${ }^{7}$ Another commentator has identified no fewer than 205 subprime and credit crisis-related securities class action lawsuits filed in the United States alone since the beginning of the crisis. ${ }^{8}$ However, estimating the ultimate cost to the insurance industry is difficult. Many - probably the majority — of these claims will fail, because proving negligence or positive wrongdoing on the part of professional firms or corporate directors is difficult: they are not liable for mere errors in judgement or losses caused by market fluctuations beyond their control. Nevertheless, insurers are generally bound to defend their clients, even when the suits they face are unmeritorious, and such defence costs always constitute a significant portion of insurers' outlay. Furthermore, liability insurance of this type is "long-tail" business, with significant delays in the notification of claims and long settlement periods. This means that the final cost of the credit crunch and financial crisis will not be known to liability insurers for many years. However, there is no sign of any shortage of supply for these lines of insurance at the time of writing. For example, while D\&O premiums for financial firms rose quite sharply in 2008 they have eased steadily since and are far below the peak attained in 2003. ${ }^{9}$ This may reflect the recent recovery in the equity markets, there being an inverse relationship between equity indices and D\&O securities actions. In any event, there seems to be no immediate likelihood of insurance becoming unaffordable, let alone unobtainable.

\section{The underwriting of credit risk by insurers}

Several types of insurance cover credit risk, either directly or indirectly. These include Mortgage Indemnity Insurance (MII, or Mortgage Indemnity Guarantee, MIG), which covers losses that mortgage lenders incur in cases where the mortgagor defaults,

\footnotetext{
5 Lloyd's (2008).

${ }^{6}$ Advisen (2008).

${ }^{7}$ Impavido and Tower (2009).

${ }^{8}$ Lacroix (2009).

${ }^{9}$ Aon (2009).
} 
leaving the lender with an asset that is worth less than the outstanding mortgage loan, and Mortgage Payment Protection Insurance (MPPI), which covers the borrower (rather than the lender) who is unable to pay the mortgage loan as a consequence, for example, of illness or loss of employment. The latter is a specialised variant of what is commonly called Payment Protection Insurance, which covers the inability of a borrower to repay other sorts of loan. Clearly, the practice of granting mortgage loans that are very high in relation to the value of the property, combined with a drop in house prices and a recession that leads to sharply rising employment - all of which we have seen in the United Kingdom and other countries recently-is likely to trigger an increase in claims on contracts of this sort. In fact, Mortgage Indemnity (MI) insurers made massive losses on this line of business in the United Kingdom in the late 1980s and early 1990s, leading to the failure of a number of specialised MI carriers. The widespread use of this insurance cover by lenders to hedge their position when granting mortgages with a high loan to value ratio had helped to fuel the credit boom of this time and contributed to a bubble in house prices. The insurers concerned failed to foresee the bursting of the bubble: therefore, when house prices fell sharply at the beginning of the 1990s, disaster befell them. However, there has been no repeat of this experience in the United Kingdom to date, largely because these lines of insurance are not used so widely as in the past.

The most important ways in which insurers and reinsurers now underwrite credit risk are through credit insurance and, in recent years, through credit default swaps (CDS). Here we consider credit insurance only. CDS, and their role in enhancing systemic risk are considered later, in the section "Systemic risk in banking and insurance".

In essence, credit insurance covers losses that insured firms suffer when their clients fail to pay for goods and services. The main risks covered are insolvency of the client or protracted default (failure of the client to pay within a set time period). In addition to these risks of commercial default some insurers also cover short-term political risks - for example, failure of a foreign buyer to pay as a consequence of war or revolution. The world market for credit insurance is dominated by three groupsEuler Hermes, Atradius/Credito y Caucion (CyC) and Coface, which have around 37 per cent, 31 per cent and 18 per cent of the market, respectively. Western Europe accounts for around 74 per cent of credit insurance buyers, with North America and Asia at just 6 per cent and 3 per cent, respectively. Important insured sectors include constructions (16 per cent), metals and engineering (15 per cent), agriculture and food (13 per cent), services (12 per cent) and electronics ( 9 per cent) ${ }^{10}$ Claims against credit insurers do not arise from purely financial transactions, such as a borrower defaulting on a loan, but from the default of buyers who fail to pay for goods or services. Therefore, credit insurers are not directly affected by the financial crisis, but rather by the increase in bankruptcies in the real economy that the crisis has brought about. Currently, credit insurers are experiencing a sharp rise in claims as the recession bites. ${ }^{11}$ However, credit insurers are well used to managing substantial peaks and

\footnotetext{
${ }^{10}$ Swiss Re (2006).

${ }^{11}$ The market leader reported a sharp deterioration in its 2008 results, with a rise of 28.2 points in its claims ratio to 81.7 per cent (Euler Hermes, 2009). Similarly, Atradius/CyC reported an increase of 55 points to
} 
troughs in their business that coincide with the business cycle. Swiss $\operatorname{Re}^{10}$ notes that the loss ratio for German credit insurers has varied from 33 per cent (in 2004) to 106 per cent (in 2006), and that dynamic management of the credit limits (in simple terms, a process whereby the credit insurer has a right to reduce or remove the credit limits for future transactions of a specific buyer if its financial positions deteriorates) enables credit insurers to ride these cycles effectively and reduce their loss ratios well before bankruptcies start to decline. Credit insurers can also refuse to renew their policies and decline new business. Evidence suggests that all this has happened, with credit insurance becoming increasingly difficult to obtain for some firms. ${ }^{12}$ Withdrawal of credit insurance can have serious consequences. First, it can create a domino effect along the supply chain in which companies that cannot buy insurance cut ties with suppliers who are judged to be high risk. Furthermore, companies in difficulty become less attractive to potential buyers if they cannot get credit insurance, making it harder for insolvency practitioners to find a buyer for the business. Clearly, the reduction in the supply of credit insurance has had some effect in reinforcing the economic downturn that has been triggered by the financial crisis. This has raised concern at government level, with the result that several countries have taken state action to maintain the availability of credit insurance in order to safeguard trading activity. ${ }^{13}$

We will return to the underwriting of credit risk by insurers in the section "Systemic risk in banking and insurance", where we consider the role of CDS in enhancing systemic risk. ${ }^{14}$

\section{The impact of the financial crisis on insurers' performance}

In this section, we evaluate the extent to which the financial crisis of the period 2007-2009 affected insurance companies across the globe and compare insurers' performance with that of banks during the same period. Our aim is to compare performance in terms of returns during this time and also to evaluate firm valuations for the period leading up to and through the crisis. We also wish to gain a greater understanding of the

97.4 per cent (from 42.4 per cent in 2007) (Atradius, 2009) and Coface 34 points, to 73 per cent (from 49 per cent in 2007) (Coface, 2009).

12 Jetuah (2009).

${ }^{13}$ They include France, which in 2008 introduced "CAP", an initiative aiming to supplement the credit insurance already provided to companies and, more recently, "CAP + ", intended to provide credit insurance cover for risks that would be uninsurable otherwise. In Canada, the government has offered up to C\$1 billion in funding to the country's six private credit insurers. In the United Kingdom, firms for which credit insurance cover had been reduced were also able to purchase top-up cover under a government scheme until recently (Department for Business Innovation and Skills, 2009).

14 On a historical note, it is worth mentioning the views on credit risk of the great insurance entrepreneur Cuthbert Heath. Known as "the Father of Lloyd's", Heath was instrumental in introducing non-marine underwriting to the Lloyd's market around the turn of the $20^{\text {th }}$ century and also in developing a credit insurance market in the United Kingdom. Heath famously formulated eight principles for credit insurance. The first laid out what should be insured: "1. Credit insurance should be concerned with credit risks for goods sold and delivered by merchants and manufacturers to their customers on credit terms in the normal course of business". The eighth stipulated what should not: " 8 . Financial credits such as loans by banks or finance houses should not be insured". 
correlation between these two markets and identify factors that might condition their relationship. In a recent study, Parsons and Mutenga ${ }^{15}$ analysed changes in insurance company valuations during the crisis on an annual basis. While this methodology is plausible, it fails to capture instantaneous daily changes in performance brought about by the impact of new information, and hence our focus on daily returns in this paper.

The methodology used is quite simple in that it focuses on daily returns in major global banking and insurance indices. Data used in computing daily returns was obtained from Bloomberg and AM Best databases. The choice of each index for inclusion in this analysis was based on two things, completeness of data and liquidity (measured by the volume of trade on the indices) for the period of study. Daily returns for the period 2004-2009 for the Bloomberg indices and 2006-2010 for the AB Best Indices were computed by taking the natural logarithms of index values for year $t$, and $t-1$. As regards the Bloomberg index, the period 2004-2009 was chosen because it represents the timeline for the financial crisis and also includes some major catastrophic events experienced by the insurance industry in the preceding years. The choice of the study period for the AM Best indices was necessarily shorter, as these indices were first introduced only in 2006. However, the AM Best indices bring an extra dimension to our study because they track global reinsurance stocks as well as Asia-Pacific insurers. The underlying assumption is that insurer equity valuations and returns are determined by investment, underwriting and capital management policies adopted by each market. Therefore, any differences in performance observed across the markets can be construed as the result of investment, underwriting and capital management policies adopted. Our study distinguishes between life, general and reinsurance companies, and aims to capture and compare performance based on the business models adopted in each sector. Since our main remit is to analyse insurance company performance during the financial crisis, we do not make a distinction between banks with different types of structure. In any event, there is no index dedicated to banks that, for example, have significant insurance interests. We believe our results to be robust as they capture the effects of underlying economic variables associated with the financial crisis on key insurance and banking value drivers. This is reflected in daily price movements and correlations.

The impact of the crisis across world insurance markets has clearly been uneven. In Figures 1 and 2 the performance of the major U.S. insurance companies is compared with that of major U.S. banks. It is clear that the performance of insurance companies and banks tend to move together when insurance sector-specific catastrophic events are absent. Thus, the only significant deviation between insurance and banking returns before the crisis was in 2004. This was due to hurricane losses in this year, which were covered largely by U.S. insurance companies. The (later) losses from Hurricanes Katrina, Rita and Wilma did not affect U.S. insurance companies to the same extent, as these were mainly covered by the Bermuda insurance market. In the period between the natural disasters of 2004-2005 and the financial crisis, the performance of the banking and insurance sectors were confined within the same narrow returns margins. However, the onset of the financial crisis in 2007 saw a significant decline in both indices and a sustained period of high volatility. Even though banks fared rather worse

\footnotetext{
15 Parsons and Mutenga (2009).
} 


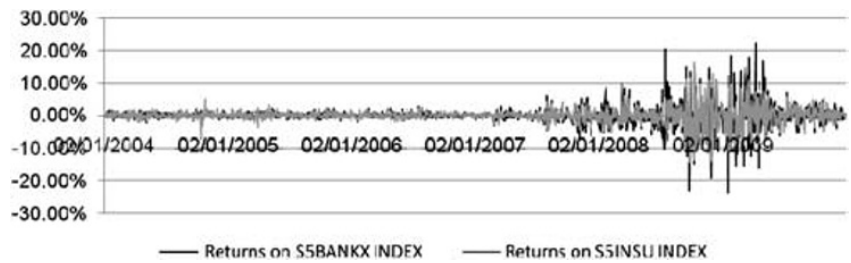

Figure 1. Returns on US banking and insurance stocks.

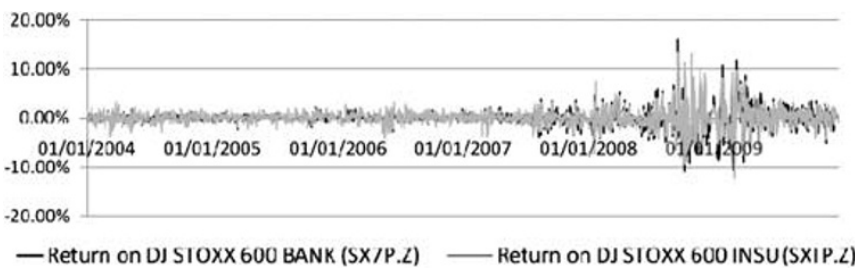

Figure 2. Returns on European banking and insurance stocks.

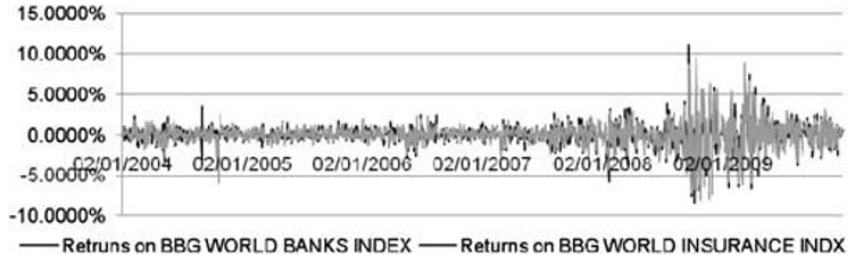

Figure 3. Returns on global insurance stocks during the financial crisis.

during the crisis, insurance stocks also suffered huge declines in their valuations. Figure 1 shows that during the crisis period, banks sustained return swings of more than 20 per cent on certain days, while insurance company stocks' daily returns swings were around 15 per cent. The same picture emerges in Figures 2 and 3, which capture the performance of European and global insurers and banks, respectively. Although the European and Global indices for both banks and insurance companies outperformed U.S. banking and insurance indices, they also suffered a sustained period when daily losses were more than 5 per cent. For all the indices analysed in Figures 1-3, there is evidence of a marked increase in correlation between banking and insurance stocks. Tests for, and a more detailed discussion of, the correlation between these indices follow in the next section of this paper.

While the changes in valuations of banking stocks was the result of toxic assets, for insurance companies the effect was a double one as it derived from both liabilities and assets. The liabilities in question mainly arose from credit-related business underwritten by monolines and major insurance and reinsurance companies, since this period contained relatively few insured catastrophic losses. 
A direct comparison between various global insurance sectors' returns for the period 2007-2009 shows that life insurers, global composite insurers, global reinsurers and (non-U.K.) European insurance companies were the worst performers during the financial crisis. The sectors least affected were Asia-Pacific, U.K. insurers and U.S. property/casualty insurance companies. Figure 4 shows that all the indices bottomed out at the same time, except for U.K. insurers, which had a fairly stable performance, as shown in Figure 5.

As noted, U.K. insurers, Asia-Pacific insurers and U.S. property/casualty outperformed all the other indices. Global reinsurers no doubt fared badly as a consequence of their incursions into the financial markets and the poor quality of assets on their balance sheets. The superior performance of U.S. property/casualty insurers is probably due to the levels of capital these insurers had managed to build up since the major catastrophes mentioned earlier. The investment policy of property/casualty insurers, with its preference for government bonds rather than equities and private bonds, also helps to explain this phenomenon. Their performance can also be contrasted with that of U.S. and U.K. life insurance companies, which had significant holdings in equities and corporate bonds. Clearly, the poor performance of equity markets, and impairments in the assets in which life insurers invested heavily, weighed down on their valuations. A closer look at U.K. insurers' performance shows a different picture from other markets, which was matched only by Asia-Pacific insurers.

It is apparent that in the United Kingdom the financial crisis did not affect the insurance sector in the same way as it affected banks. As shown in Figure 5, the value of U.K. banks (FTBK Index) dropped nearly 78 per cent between 2004 and the peak of the financial crisis in early 2009. U.K. insurance companies (FTIC Index) during the same period outperformed banks. Their valuations were 79 per cent above those of 2004 in 2007, but dropped by 54 per cent from this peak when AIG's problems

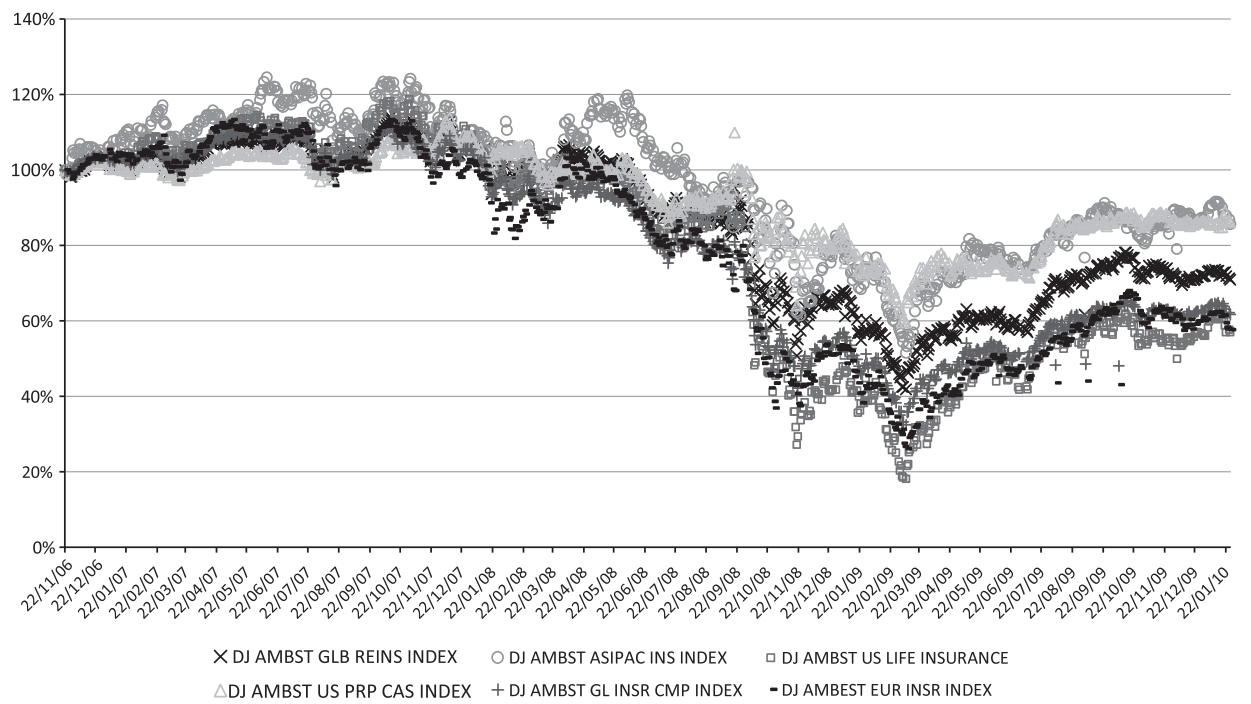

Figure 4. Performance of insurance companies during the financial crisis. 


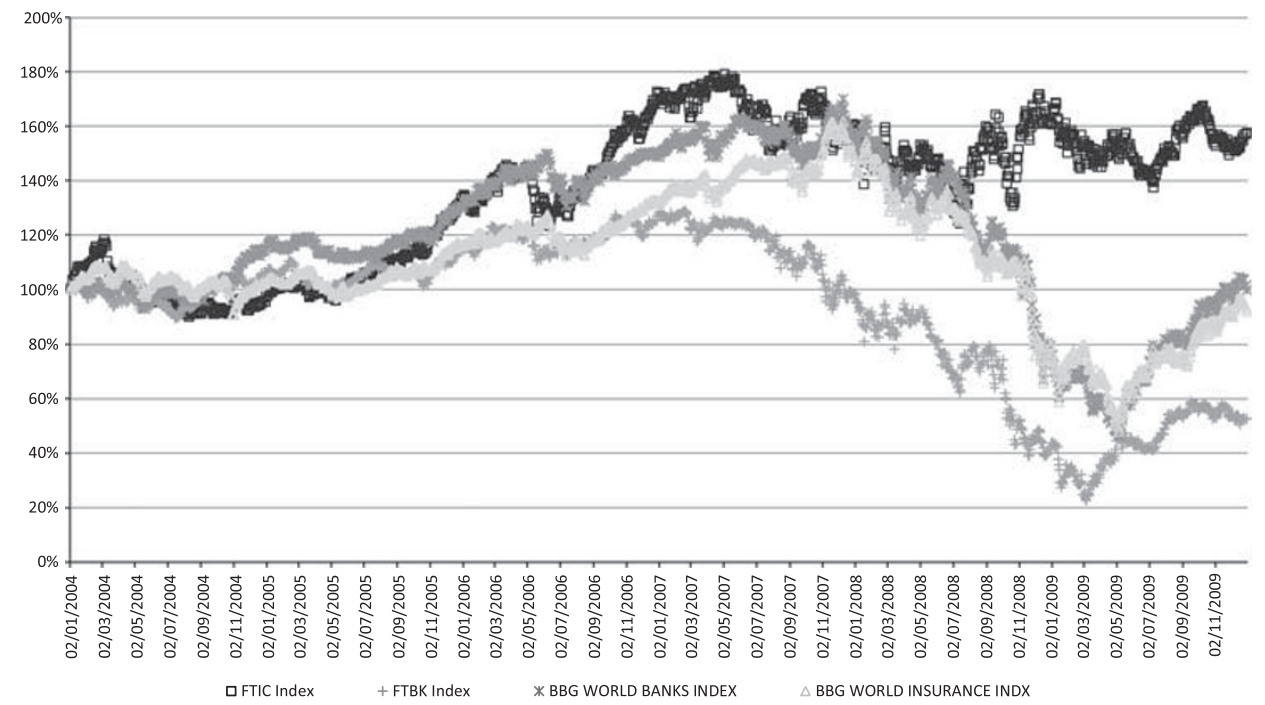

Figure 5. Performance of banks and insurance companies during the financial crisis.

emerged in 2008. However, the valuations of U.K. insurance companies did not suffer the sustained declines seen in the banking sector, which only bottomed out after a second wave of government bail-outs in 2009. The reason for the divergence between the performance of banks and insurance companies lies mainly in the quality of their assets and their degree of exposure to credit-related losses.

U.K. insurance companies also fared better than the global banks (BBG World Banks Index) and insurance companies (BBG World Insurance Index). The performance of global banks and insurance companies during the financial crisis was pretty much the same. One plausible explanation for this is the bancassurance models followed by major banks and insurance companies that make up these indices. Another explanation is found in the high level of exposure that the major banks and insurance companies had to toxic assets and liabilities underwritten on these assets. The cross holdings between banks and insurance companies in Europe, which are not highly prevalent in the United Kingdom ${ }^{16}$ provide an explanation for the contrasting performance of these markets. Again, in the United Kingdom the insurance market is not dominated by a few big companies. This is not the case in Europe, where big companies with cross-bank ownership dominate the market to a greater extent. Their dominance weighed heavily on the indices during the crisis and, at least, calls into question the strength of the bancassurance model. We can safely conclude that size and dominance in a market are not good for the stability of an economic system. In the banking sector, size and dominance clearly played part in the underperformance of banking stocks and subsequent damage to the worldwide economy. This is reflected in

\footnotetext{
${ }^{16}$ Mutenga et al. (2008).
} 
the recent proposals of the Obama Administration, which highlight size and dominance as major contributors to the global financial crisis. ${ }^{17}$

Finally, we can note that while many banks breached their solvency capital requirements in the course of the crisis, most insurance companies remained within their solvency margins. The use by banks of softer forms of capital to lever their capital structures also helps to explain their weaker financial position during the crisis. Although insurance companies under the Solvency I requirements are allowed to use softer forms of capital, the proportion allowed to them is much lower than that permitted by Basel II. The big insurance companies that took a less conservative approach to using softer forms of capital are those that had their stock valuation weighed down most heavily, especially in Europe. This calls into question the right to use such softer forms of capital under the Solvency II regime. Since the use of softer forms of capital to lever the capital structure played such a significant role in banking collapses, there is arguably a need to increase the proportion of pure equity used by insurance companies as risk capital, so as to limit the level of leverage allowed to them.

\section{Systemic risk in banking and insurance}

Financial institutions such as banks and insurers are, of course, constituents of the wider capital market. Thus, in addition to their firm-specific risks, they are exposed to market volatility and correlation. Observed volatility in capital markets such as the recent "credit crunch", which was largely generated by substantial declines in the value of derivatives (collateralised debt obligation/Asset-backed security: CDO/ABS) with underlying U.S. subprime real estate collateral, can leave firms exposed to systemic risk. However, the term "systemic risk" is somewhat ambiguous with regard to both its definition and derivation. A widely accepted definition of systemic risk is that of Csiszar $^{18}$ who characterise it as "the risk that the failure of a participant to meet its contractual obligations may in turn cause other participants to default, with the chain reaction leading to broader financial difficulties". However, this definition includes only the sort of "micro" systemic risk represented by a cumulative loss function caused by a domino effect, as illustrated in Figure 6.

The alternative form of systemic risk, known as "macro-systemic risk", is one which is not dependent upon a cumulative loss function. In this instance, a single exogenous event leads to simultaneous adverse effect on multiple entities. This was precisely the case during the Lehman bankruptcy in September 2008, which sent a systemic shock throughout the credit market, restricting global liquidity. In this paper, we use the term systemic risk to include both its "micro" and "macro" forms.

Systemic risk is traditionally regarded as a phenomenon most present in the banking sector. This view is supported by the direct positive correlation found in historical

\footnotetext{
${ }^{17}$ More generally, there is now a growing debate about the maximum size of financial sector that a given economy can safely sustain in relation to its tax revenues and GDP. The extreme case is Iceland, where problems in a grossly inflated banking sector brought down the whole economy.

${ }^{18}$ Csiszar (2002).
} 


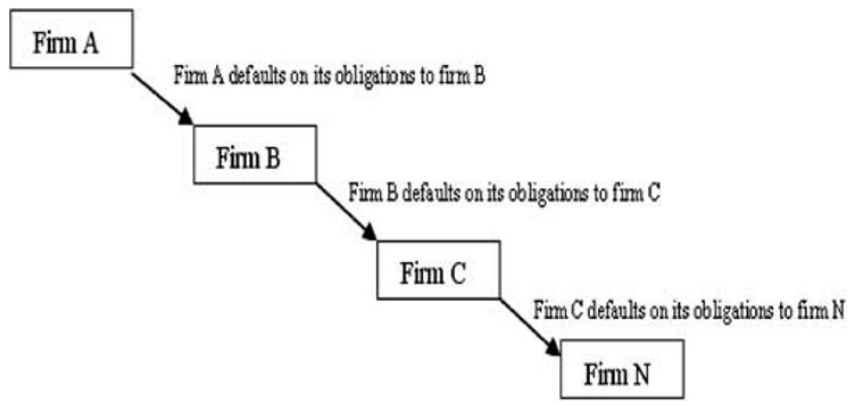

Figure 6. Micro-systemic risk.

equity returns ${ }^{19}$ as well as counterparty credit links established by inter-bank lending markets. ${ }^{20}$ The recent subprime crisis was only one of many historical events that highlighted this web of exposure between banks, ultimately leading to multi-billion write-downs in securitised trading assets and trillions being wiped of international equity markets. However, unlike many past crises, the U.S. subprime crisis had a far wider impact than in the banking sector alone. Insurers, which were typically regarded as a being largely segregated from the rest of the financial industry, experienced significant write-down losses on their investment portfolios. AIG became the most notorious case when it was bailed out for a record US\$85 billion by the U.S. government following its inability to meet its investment obligations (in particular regarding its CDS contracts).

Prior to the recent financial crisis, the insurance sector was believed to be largely immune to systemic risk. The lack of a significant "insurance crisis", as discussed in the section "Previous insurance "crises", , suggested that the risk of systemic failure was minimal in the insurance industry. Certainly, unlike banks, insurers do not face the risk of financial runs caused by clients withdrawing funds when they begin to fear that the firm will not be able to meet its contractual obligations. Instead, insurers are only obliged to pay when a client suffers a loss on an existing policy (in the case of non-life insurance) or on death of the insured or maturity of the plan (in the case of life insurance). $^{21}$

Of course, insurers are exposed to the underwriting cycle, with alternating periods of soft markets (low premium) and hard markets (high premium), as illustrated in Figure 7.

The insurance industry is equally susceptible to the effects of major disasters that they sell protection against. Furthermore, over the last decade the magnitude and frequency of such fundamental risks faced by insurers have undoubtedly increased, partly as a consequence of an increase in man-made catastrophes, such as terrorist

\footnotetext{
${ }^{19}$ De Nicolo and Kwast (2001) and Gropp et al. (2004).

${ }^{20}$ Buhler and Prokopczuk (2007).

${ }^{21}$ It is true that life insurance policy-holders might be tempted to prematurely cash in life policies with a savings element if they lose confidence in the insurer concerned, but penalties for early exit usually provide a considerable disincentive against precipitate action of this sort.
} 


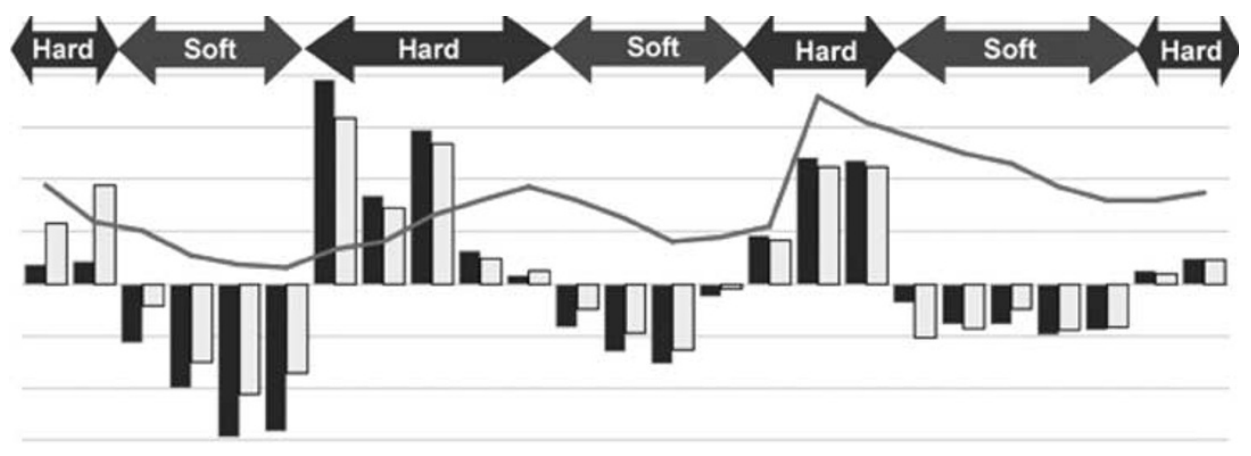

Figure 7. Insurance underwriting cycle.

attacks, and partly through the concentration of insurance risks in danger zones. As a result of this increased exposure, insurers have turned more and more to the capital markets and alternative risk transfer (ART) mechanisms to mitigate the impact of catastrophes on their balance sheet. ART gives insurers access to financial markets where they can directly transfer and finance their risks using instruments such as CAT bonds and insurance-linked securities (i.e. insurance funds). This movement towards the capital market has increased the exposure of insurers to the banking sector, which acts as the counterparty to capital market arrangements made by the insurer via ART investments. As a consequence of this extension in activities, there is a copula effect between the banking and insurance sector. Table 1 shows the average equity correlation between a selected group of banks and insurers between 2004 and 2009.

As shown above, the average correlation between banking and insurance equity values has increased significantly in recent years, with a correlation delta of 86.1 per cent (2004-2009). It must be noted, however, that this result does not suggest that the insurance and banking industries face systemic risk in pari passu manner. The banking sector is more susceptible to systemic risk due to lower capital to asset ratios, lower levels of cash reserves and the highly structured and illiquid instruments traded by banks. Nevertheless, this result does suggest that the insurance industry's pursuit of capital investment as a value driver to compensate for underwriting results has resulted in its being exposed to market risk, which can be defined as "potential losses owing to detrimental changes in market prices and/or other financial variables influenced by prices". This is precisely what has happened with the recent subprime crisis, where the decline in the value of CDOs and ABS led to write-down losses suffered by both banks and insurers.

Along with increased participation in capital market instruments, the insurance industry is further aligned to risks faced in the banking sector, including systemic risk, through the significant holdings they have in banks. Such holdings will clearly leave insurers' own performance subject to that of the banking sector. A relevant example is found in the German insurer Allianz SE that owned outright Dresdner bank in the period between 2001 and 2008. In this case, Allianz suffered a negative impact on its 
Table 1 Bank and Insurance Equity correlation

\begin{tabular}{lcccc}
\hline Condition & $2004-2006$ & $2006-2007$ & $2007-2009$ & $\begin{array}{c}\text { Average } \\
\text { correlation }\end{array}$ \\
\hline Bank Equity vs. Insurance equity (\%) & 29.82 & 41.35 & 55.50 & 42.22 \\
\hline
\end{tabular}

For historical correlation matrix and test details see Appendix A.

Source: Bloomberg Plc.

Table 2 Bank and Insurance index test

\begin{tabular}{lccr}
\hline Condition & Correlation & Beta & $R^{2}$ \\
\hline Bank Index vs. Insurance Index & $66.12 \%$ & 0.64 & $46.48 \%$ \\
\hline
\end{tabular}

For correlation/beta $/ R^{2}$ matrix and test details see Appendix B.

Source: Bloomberg Plc.

Table 3 S\&P 500 Bank and Insurance index historical test

Average price S5INSU INDEX Average price S5BANKX INDEX Average spread Average correlation

\begin{tabular}{llcc}
\hline 297.48 & 295.56 & 1.93 & $76.2 \%$ \\
\hline
\end{tabular}

Source: Bloomberg Plc.

equity and balance sheet as well as key capital ratios following multi-billion writedowns by its banking subsidiary.

Table 2 shows the average correlation/beta $/ R^{2}$ between a selected group of global bank and insurance indices in the period 2007-2009.

The results above suggest that there is a relatively strong correlated relationship between the performance of the banking and insurance indices, with each index acting as a relatively strong determinant on the performance of the other. In particular, the BBG World Insurance \& BBG World Bank indices have a regression/correlation estimation of 85.8 per cent/92.6 per cent while the Citigroup Eurostoxx Insurance \& Bank indices have a regression/correlation estimation of 80.8 per cent/89.9 per cent, respectively. The copulament between the banking and insurance sector is further illustrated by the historical analysis of the S\&P500 Banks (S5BANK) and S\&P500 Insurance (S5INSU) indices. Figures (8)-(10) show the historical correlation/price movements of the two indices as well as their regressive relationship in the period 2004-2009.

As we can see from Figures (8-10) and the results in Table 3, there is a strong positive correlation between the two indices. The movement of the two indices during the assessed period signifies a bivariate normal distribution with the two indices indicating a strong explanatory relationship one upon the other. The only key outlier in the results is during 2005, where the correlation between the two indices decreased due to the losses sustained by the insurance industry, following Hurricane Katrina. This loss was a result of underwriting risk, which was specific to the insurance industry. 


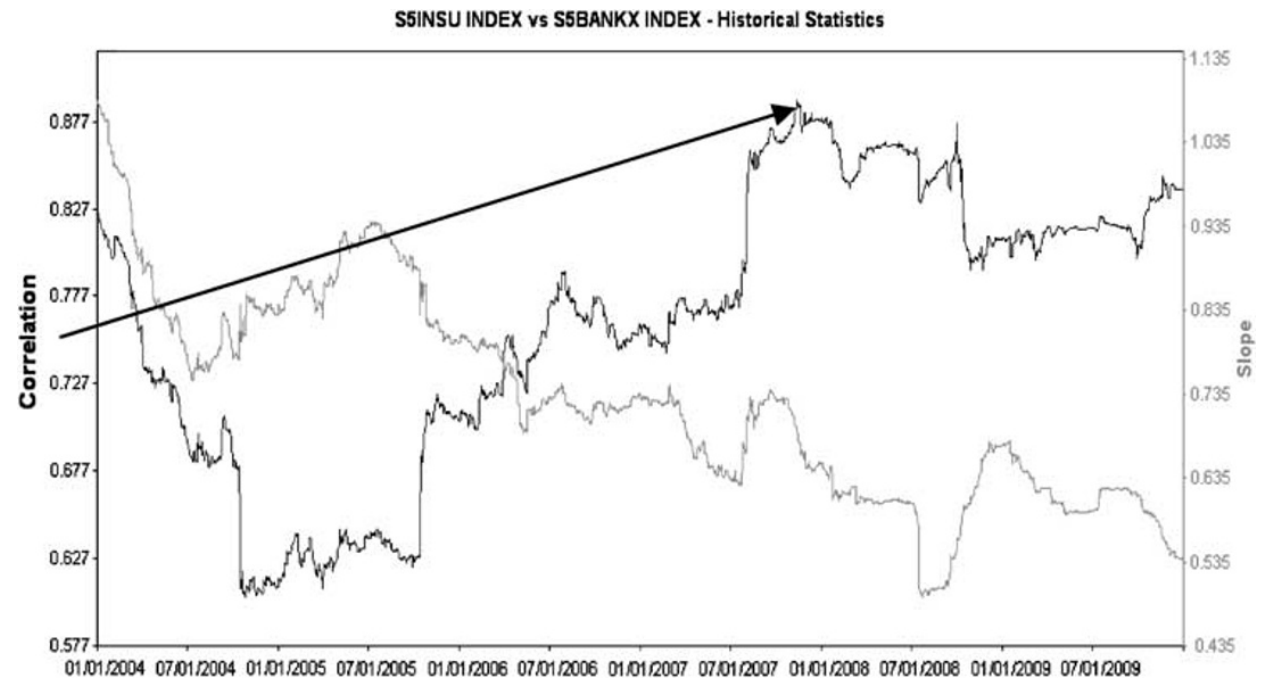

Figure 8. Historical correlation (2004-2009).

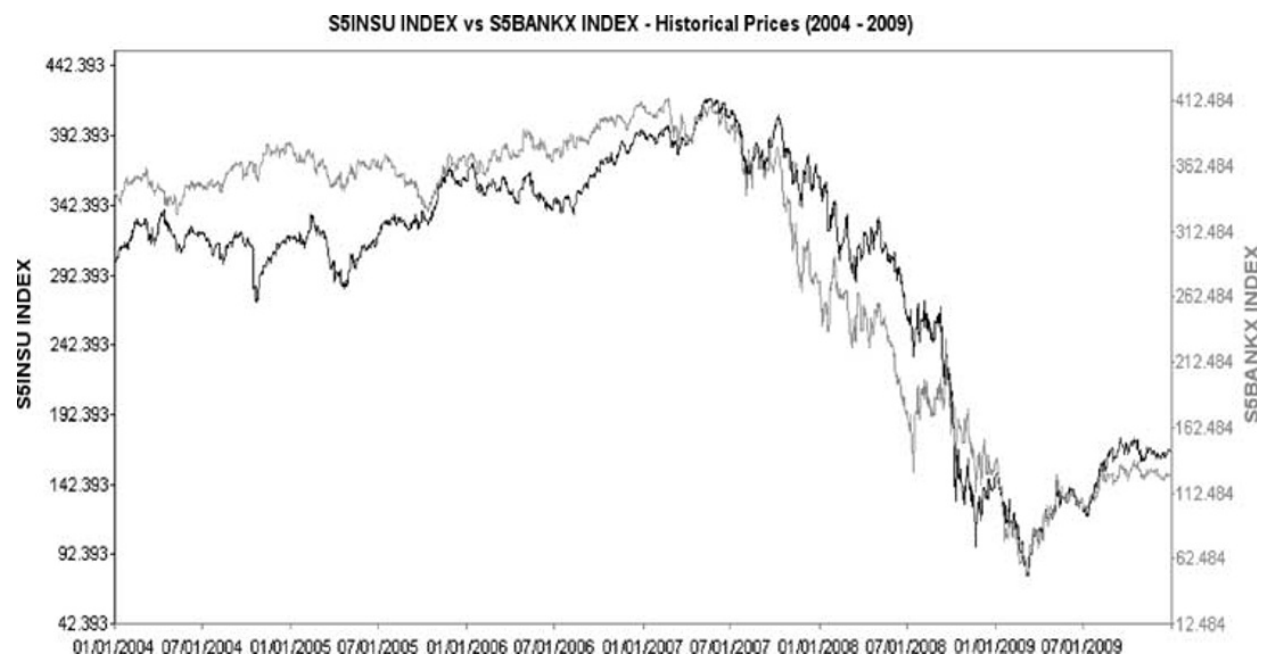

Figure 9. Historical price movement (2004-2009).

The underlying relationship between the banking and insurance sector is quite obvious from the above analysis, and the relationship has clearly strengthened during the last decade. As we have seen, this relationship has arisen both from the insurance sectors' growing participation in the capital markets and its adoption of bancassurance models, together creating a systemic link between banks and insurers. However, the systemic risk arising from bancassurance activities may well diminish in the 


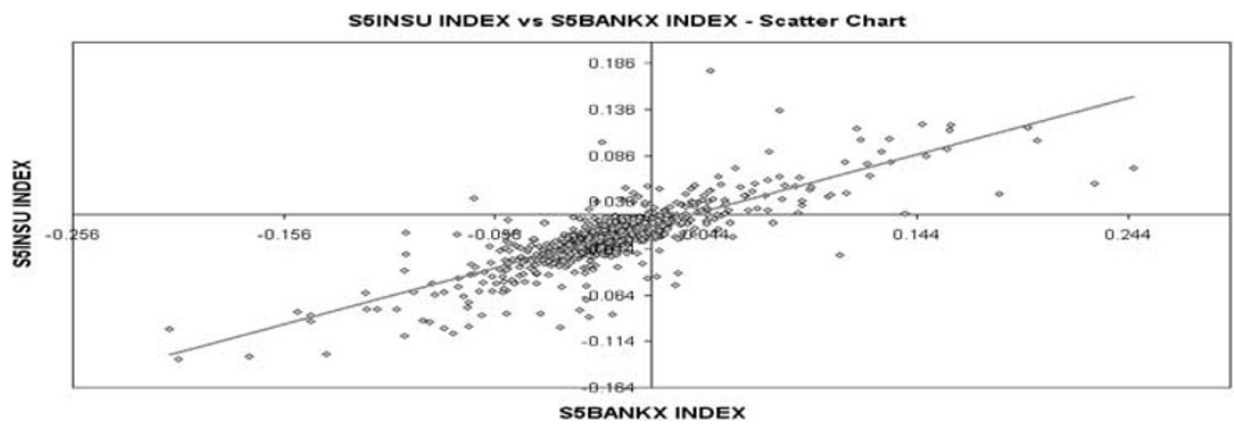

Figure 10. Regression (2004-2009).

aftermath of the financial crisis, following significant withdrawals from the banking sector by a number of insurers. This is considered in the final section of our paper.

\section{Reinsurance and systemic risk}

From the analysis above it is clear that insurers face greater systemic risk from their affiliations with the banking sector than from within the insurance sector itself. This is largely because there is limited trading between insurers. As underwriting risks are not usually transferred between carriers, credit risk is minimal. However, there is obviously an exception to this rule, in the shape of reinsurance and retrocession. Reinsurance, in essence, is insurance for primary insurers, whereby the latter, for a premium, cede away some of their underwriting risk (normally large/complex risks in concentrated areas) to reinsurers that, in turn, may further cede parts of the risk to other reinsurers (retrocession). On average, 6 per cent of risk is transferred worldwide by primary insurers to reinsurers, which in turn transfer approximately 20 per cent to other reinsurers. This process of risk transfer between insurers and reinsurers, and reinsurers to other reinsurers, poses the question of whether a systemic link is created. The question for primary insurers is whether, by transferring a portion of their risk to reinsurers, a significance credit risk is assumed. For the reinsurer, there is also a potential credit risk in the shape of other reinsurers to which they in turn have ceded risk. Furthermore, reinsurers are also significant participants in the capital markets as they, like primary insurers, try to diversify some of their risk via credit-linked securities. This link between the reinsurance market and the banking sector could further expose insurers to systemic risk.

In fact, earlier studies suggest that systemic risk posed by reinsurance is relatively weak. Insurers generally diversify their risk to multiple reinsurers, thus avoiding a large-scale credit risk with any particular reinsurer. Reinsurers further diversify their risk by holding a diversified pure risk (e.g. earthquakes, fire and liability) portfolio, thereby mitigating the prospect of multiple large-scale losses. According to a study by Swiss Re, ${ }^{22}$ only 24 reinsurers failed in the period 1980-2002 and these failures affected on average only 0.02 per cent of the total premiums transferred to reinsurers in this 
Table 4 Insurer \& reinsurer equity \& CDS test

\begin{tabular}{lcr}
\hline Condition & Correlation $(\%)$ & $R^{2}(\%)$ \\
\hline Insurer vs. Reinsurer (Equity) & 50.17 & 27.21 \\
Insurer vs. Reinsurer (CDS) & 42.13 & 23.53 \\
\hline
\end{tabular}

For correlation $/ R^{2}$ matrix and test details please see Appendix C.

Source: Bloomberg Plc.

period. Table 4 shows the correlation $/ R^{2}$ estimates between insurers and reinsurers for the underlying CDS (five-year spread) and equity for the period 2007-2009.

As we can infer from the results, the performance of insurers and reinsurers on both the equity and CDS sides are largely independent of each other, suggesting little influence and hence little systemic link, which confirms existing studies. On the other hand, the correlation results suggest that there is some degree of correlation in the equity and CDS values of insurers and reinsurers. This correlative link is probably due to the credit link that both the insurance and reinsurance markets have with the banking sector as a result of their risk diversification strategies via the capital markets. It would seem, therefore, that the potential for systemic risk in insurance and reinsurance networks could only be realised by either an unanticipated exogenous shock far greater than any that has yet occurred or in a case where the reinsurer was part of a financial conglomerate. If a reinsurer had a stakeholding relationship with another financial conglomerate, for example a bank/insurer, then the bankruptcy of the reinsurer could result in reduced confidence in the bank/insurer's credit worthiness. This potential for systemic risk would be reduced if the use of shared capital between conglomerates was prevented.

\section{Systemic risk in life and non-life insurance}

In this section, we aim to compare the degree of systemic risk within life and non-life insurance markets. In principle, systemic risk would seem to be of much greater concern in the life segment, owing to the greater level and diversity of its investments. Non-life involvement in the capital market is predominately based on derivatives with underlying insurance events acting as triggers. Let us take the CAT (catastrophe) bond as an example. Here the insurer issues the bond and transfers the cash inflow from the issue to a Special Purpose Vehicle (SPV). The insurer will continue to pay the investors interest via the SPV until a disaster occurs. If the disaster occurs the insurer will stop paying investors and use the issue proceeds from the SPV to offset the claims made in conjunction with the disaster. The risk here lies with the investor and not the insurer. The insurer is only exposed to risk if the issue proceeds are invested in securitised funds with low-rated collateral. However, normally the issue proceeds are invested in risk-free treasury bonds issued by AAA-rated governments such as the United Kingdom or the United States. The situation is different for life insurers that invest in underlying securities that are subject to market volatility, such as corporate bonds. Life insurance products are based on the duration of human life and promise to pay fixed sums, set at inception of the contract, such payments not being so subject to the 
144

random occurrence of an unknown event. Therefore, life insurers invest in bonds and funds to achieve a rate of return requisite with their future obligations. These forms of investment carry a higher degree of market risk than non-life investments, which makes life insurers more susceptible to systemic risk during periods of market downturn. To test the validity of this thesis, the U.K. FTSE 350 Life and FTSE 350 Non-life insurance indices were observed from 2004 to 2009.

Figure 11 and Table 5 show the historical price movement of the two indices.

As we can see, the life insurance index experienced greater volatility than the non-life index during market downturn, especially in 2008 during the equity market slump following Lehman Brothers' bankruptcy and the near-demise of AIG. This observed volatility for the life index is a direct result of life insurers' aggressive investment strategies in the bond, equity and fund markets in which non-life insurers were only minor players. Such volatility in investments ultimately makes life insurers more susceptible to systemic risk than non-life insurers.

The role of CDS in creating systemic risk in the banking \& insurance sectors

In the section "The underwriting of credit risk by insurers", we discussed the underwriting of credit risk by insurers through the medium of credit insurance. We now consider the impact of a much more recent financial instrument. Since their conception in the early 1990s, CDS have become widely used credit derivative tools in the banking

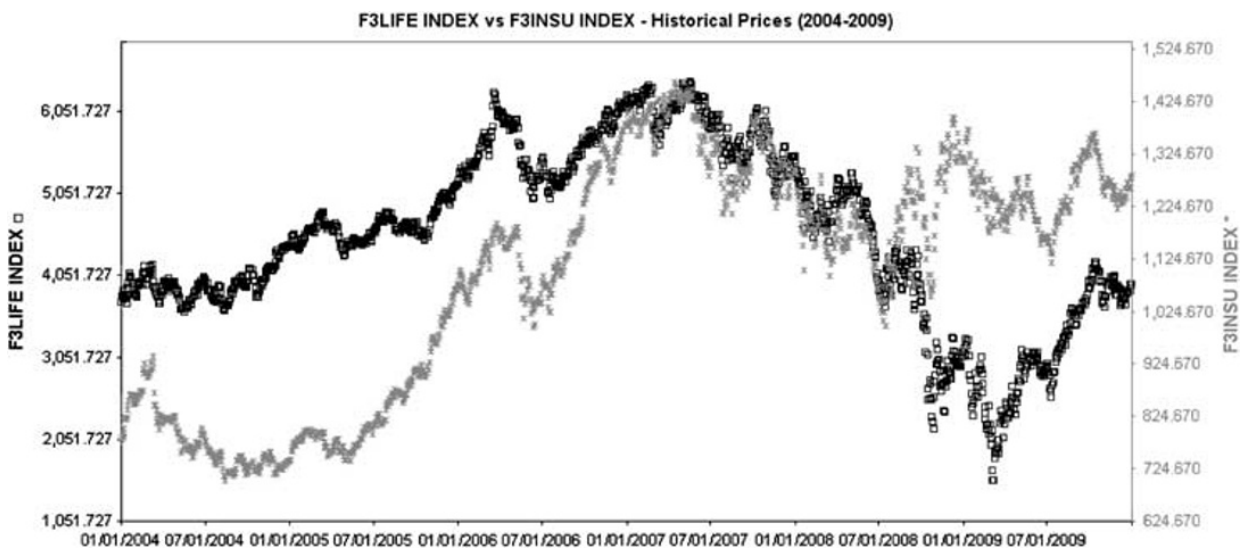

Figure 11. UK FTSE 350 Life and Non-life index historical price movement (2004-2009).

Table 5 UK FTSE 350 Life and Non-life index historical price levels

\begin{tabular}{lrccrrr}
\hline Index & Open & Last & Average & Std Dev & Max & Min \\
\hline F3LIFE INDEX & $3,729.60$ & $3,938.28$ & $4,555.58$ & $1,059.28$ & $6,414.70$ & $1,539.27$ \\
F3INSU INDEX & 783.40 & $1,286.11$ & $1,097.54$ & 223.48 & $1,463.20$ & 700.90 \\
\hline
\end{tabular}

Source: Bloomberg Plc. 
Pays CDS Spread (bps) periodically (\% of notional)

\begin{tabular}{|l|l|l|} 
Protection Buyer & Protection Seller \\
\hline
\end{tabular}

Pays 1- Recovery Rate (\%) in the event of default of the reference asset

Reference Asset

Figure 12. Conventional CDS.

sector. A CDS is essentially a multi-period credit option that provides the holder (long party-short credit risk) protection on a reference asset (e.g. corporate bond). In return for this protection the long party must make periodic payments based on a percentage of notional to the protection seller (who is long credit risk). The protection buyer will continue to make payments until either maturity or at default of the underlying reference asset. In the event of a default, the protection buyer provides the bond (if physical settlement) to the protection seller in return for par. Figure 12 illustrates this process.

The traditional purpose of CDS contracts was to provide a hedge and risk management tool whereby the protection buyer would enter into a swap to mitigate and diversify their credit risk and balance out the portfolio beta in accordance with their risk appetite. On the face of it, a CDS contract looks like insurance for the financial world. However, unlike traditional insurance, there is no requirement for the protection buyer to actually hold the underlying asset at the time when the contract begins (i.e. no insurable interest required). This fundamental difference lies at the heart of recent market woes for firms such as AIG, Bear Sterns and Lehman Brothers (among many others), because the CDS contract has very quickly become a speculative tool to bet on market movements. Accordingly, a huge number of banks have been using CDS for basis trades and arbitrage strategies in the cash and synthetic markets.

Insurers' and reinsurers' involvement in the CDS market is predominately on the sell side (i.e. sale of protection to banks and other financial institutions). According to the British Bankers' Association (BBA), insurers and reinsurers accounted for approximately 17 per cent of the CDS market in 2006 (when the CDS market stood at US\$62.17 trillion). This significant level of market involvement has made insurers and reinsurers more susceptible to the recent subprime-originated credit crisis. This was certainly the case for the insurance giant AIG - the world's biggest underwriter of credit protection. AIG suffered massive losses as a result of its holding significant short positions on CDS contracts with Lehman Brothers as the underlying reference as well as CDOs backed by a pool of subprime mortgages. In 2008, AIG wrote down the value of its CDS book by over US\$20 billion ${ }^{23}$ and, coupled with the infamous period of Lehman's collapse (September 2008), this triggered a significant macro-systemic event, as illustrated in Figure 13 by the CDS delta analysis on the five-year CDS between September 2008 and October 2008 for selected banks, insurers and reinsurers.

${ }^{23}$ RKMC (2008). 


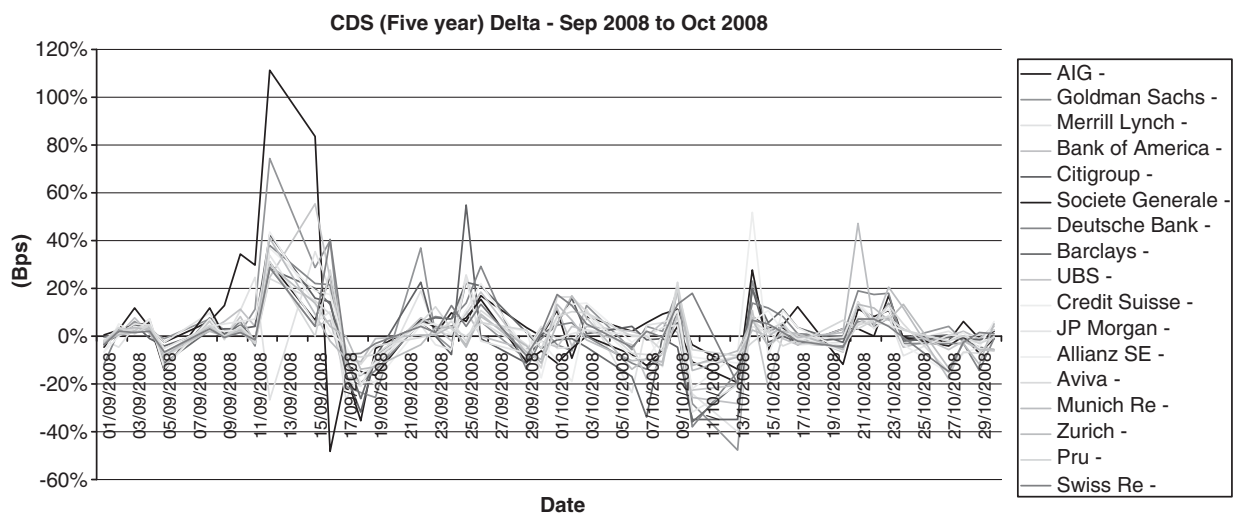

Figure 13. Selected bank/insurer/reinsurer five-year CDS day-to-day change (delta).

Source: Bloomberg PLC-See Appendix D for daily change in CDS for period September 2008 to October 2008.

Note: Key dates: 11-13 September 2008: Lehman searches for potential buyer (no success), 14 September 2008: Lehman states it will file for chapter 11 bankruptcy, 15 September 2008: Lehman files for chapter 11 bankruptcy.

Although this systemic event was triggered largely by Lehman's demise, it was exacerbated by AIG's acting as a major counterparty to CDS contracts with other financial institutions. AIG was unable to fulfil its obligations and ultimately required a record government bail-out. This sent a systemic shock across the entire global market, leading to a free fall in the equity, bond and CDS markets. The consequence of this was significant losses for banks, insurers and reinsurers. Insurers' exposure on the sell side is further illustrated by the reinsurer Swiss Re, which reported a loss of US\$1.5 billion (2007-2008) for losses connected to the sale of protection on CDOs backed by subprime mortgages, which in turn triggered a credit event. The reinsurer needed to secure a major capital influx following these write-downs, of which US\$3 billion came from Berkshire Hathaway. Thus, by being on the sell side, insurers face the risk of higher payments, due to increased default probabilities, which can far outweigh the premium inflows (the case for both AIG and Swiss Re, among others). However, on the other side of the coin, insurers also pose a risk for financial institutions, such as banks, due to counterparty risk. In fact, within the CDS market it has become increasingly difficult to determine the financial strength of the protection seller. The lack of significant regulation in the CDS market has meant that protection sellers have not been bound by the same regulatory capital requirements that financial institutions face for their other business activities.

Returning to AIG, it is clear that the insurer was laid low, not by the risks of its core insurance business, but rather as a consequence of its indulgence in the capital markets. Insurers such as AIG sold protection based on an implied hazard rate that they believed to be compensated by the premium inflow. However, the volatility that surfaced with regard to the probability of payments (i.e. defaults) connected to protection sold on CDOs/ABS/CLOs and other securitised assets was clearly not reflected in the premium. 
In addition to the sell side, insurers are also exposed to systemic risk via the purchasing side. Insurers commonly purchase protection on their own investment holdings such as bonds and loans. Like banks that purchase protection from insurers, insurers here are exposed to counterparty credit risk (i.e. the short party may not compensate the insurer in the event of default on the underlying asset). Unlike traditional CDS arrangements where the trade was between two constant parties for the duration of the contract, the modern day CDS contract can change hands many times through the secondary market. It may then become difficult to identify the counterparty to the trade in the event of default, leading to difficulties in unwinding the trade. All this leaves the insurer facing significant credit risk, especially if the underlying asset is a high notional securitised asset that could severely impact the insurer's balance sheet.

The generation of systemic risk through the use of CDS is further illustrated by the monoline crisis of 2008. Monolines are insurers that can write one line of business only (financial guarantees). Traditionally, Monolines provided protection on municipal bonds; however, over the last decade they have also participated in the structured market (ABS/CDO) in order to attain greater margin levels. Prior to the recent credit crisis, banks had used monolines extensively to reduce capital requirements. This was achieved by buying protection from monolines that were AAA-rated. Thus, in essence, banks leveraged off this AAA-rating. This course of action left banks undercapitalized and monolines heavily short on CDS contracts. The problem for monolines arose out of their treatment of capital backing for writing such protection. Monolines such as Ambac were significantly under-capitalised in relation to their structured business. The separation and level of capital required for the structured business led to rating agencies such as S\&P, Moody's and Fitch downgrading the monoline sector (FT, 19 January 2008). The loss of their coveted AAA status limited the ability of the monolines to write further business. This led to their suffering multi-billion writedowns (FT, 23 January 2008), causing a ripple effect on the CDS, equity and bond markets. The bond market, in particular, saw previously high-rated bonds downgraded as a consequence of downgrades in the monoline sector. This series of events transmitted systemic shocks through the global markets, further illustrating the growing links between insurers and banks.

Finally, the exposure of banks to insurers via the CDS market is further highlighted by typical funding arrangements between the two. It has been argued by many (including a recent paper by the $\mathrm{IMF}^{24}$ ) that insurers have limited funding requirements via banks. However, this is not wholly the case. Although insurers are largely funded via premiums collected from clients, they often require funding for their investment vehicles. Insurers usually set up SPVs for their investment transactions (SPVs are normally highly rated, thus opening up funding opportunities). Insurers commonly look to the banking sector for funding and, through the use of CDS, they can provide protection to banks in return for that funding. Figure 14 illustrates a typical funding arrangement between banks and insurers.

${ }^{24}$ IMF (2009). 


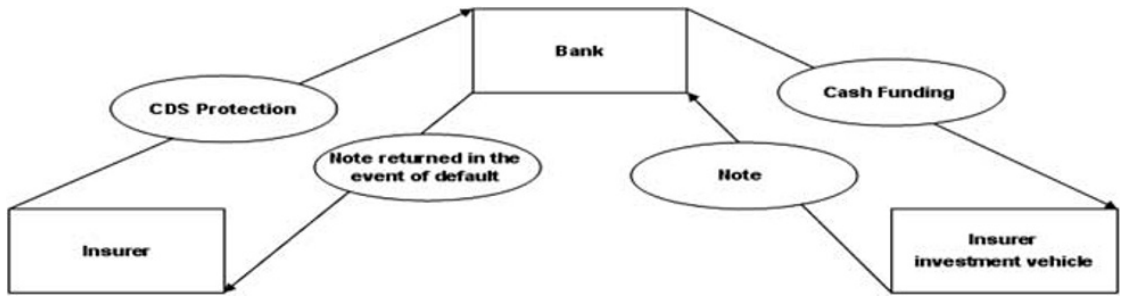

Figure 14. Funding arrangement between insurer and bank.

Essentially, Figure 14 depicts a credit-linked note. Potentially, the bank is thereby exposed to two risks: first, the risks of default on the note issued by the insurer's investment vehicle and, second, the risk that the insurer will not honour its protective obligation on the underlying note issued by the investment vehicle to the bank. If the funding arrangement between bank and insurer is a significant one, this could place a significant strain on the bank. There is then a potential knock-on effect on the bank's ability to meet its obligations to other counterparties leading, potentially, to a microsystemic event.

\section{Conclusion}

In April 2009, the IMF projected total losses from the financial crisis of around US\$4.1 trillion, of which about two-thirds was expected to constitute write-downs by banks and one-third losses suffered by insurance companies, pension funds and other financial institutions. ${ }^{24}$ Clearly, the effects of the financial crisis on insurance markets have not been insignificant, even though they have been less severe than in the banking sector. Nevertheless, and despite the losses the industry has suffered, there have been relatively few insurance failures. Indeed, the presence of insurers and their general robustness in the face of the crisis may well have had a stabilising effect in overall economic terms. ${ }^{25}$

As we have seen, the impact of the crisis on individual insurers has been very uneven. The firms most directly affected are the specialist financial guarantee insurers (such as the U.S. monolines), companies (such as AIG and Swiss Re) that extended their operations beyond traditional insurance business into risky areas of structured finance and, to a lesser extent, firms writing lines of insurance business that are particularly sensitive to an economic downturn, such as credit and liability insurers. Unsurprisingly, "bancassurers"-integrated financial services providers and insurers that have close affiliations with banks - have been among the major insurance market victims. Of course, all insurance firms have suffered an erosion in the value of their

${ }^{25}$ A recent report produced by PricewaterhouseCoopers (PWC) for the Association of British Insurers found that corporation tax paid by U.K. insurers fell by only 8.4 per cent in 2008 - that is, during the depths of the crisis - compared with a fall of 39 per cent for the financial services sector as a whole (ABI News Release, 26 January 2010, Ref 10/10). 
assets and, for the reasons given earlier, life insurers have suffered more than non-life firms. We have seen that at some points in the emerging crisis insurance stocks (especially life insurance) have fallen as sharply as banking stocks - notably in late 2008 when news first broke on the parlous state of AIG. Insurance stocks have since recovered to some degree, no doubt because investors have started to believe that the contagion of insurance markets might be less severe, and less general, than they first imagined.

How will insurance markets change as a consequence of all this? In due course, when the current volatility and uncertainty in credit and equity markets has subsided, we may see a rise in M\&A activity among insurance firms, with smaller insurers that have been weakened by the crisis becoming attractive targets for larger, wellcapitalised companies that have emerged in better shape. A question mark certainly hangs over future developments in the field of bancassurance. Until recently, bancassurance activity-where insurers use banks to distribute their products, or banks and insurance firms integrate more fully within one corporate structure-has been attractive to banks and insurers alike, generating potential economies of scale and scope, opportunities for cross-selling and new income streams. In the current climate some of these benefits look questionable. Banks with well-established, stable and profitable insurance businesses might want to retain them, at the very least until they can be sold on better terms. However, in the current climate, banks have come under pressure to sell off their insurance subsidiaries and withdraw from insurance activities in order to preserve capital and concentrate resources on core activities. Governments and regulatory bodies have clearly contributed to this pressure, partly to minimise the need for state support and partly, one suspects, because of a growing consciousness of the enhanced systemic risk and regulatory challenges posed by large, complex financial conglomerates. Given all this, the trend away from bancassurance structures in some markets at least is not surprising ${ }^{26}$ even though support for the bancassurance model remains strong elsewhere. ${ }^{27}$ From the point of view of insurance firms themselves, the benefits of close affiliations with banks look increasingly dubious. For one thing, insurers have, in the past, used bank distribution channels in

${ }^{26}$ The most notable example is ING, perhaps the major European proponent of the bancassurance model. Data from Reuters showed that despite its insurance operations generating in excess of 80 per cent of revenues in 2008, ING had a price to book ratio of 0.54 compared to the average 1.05 for the DJStoxx European Insurance sector (Reuters, 2009), highlighting the strain on the insurance operations of ING as a result of its conglomeration with its banking operations. A recipient of $€ 10$ billion in public aid, ING has now been obliged to sell its insurance operations along with its real estate credit operations in the Netherlands and its U.S. online bank. In effect, ING has been obliged to give up its notorious "double leverage" by virtue of which regulators had allowed ING to operate with lower capital at group level to reflect its diversified and supposedly lower-risk model. Other examples include Belgian Bank KBC, which has been compelled to give up its insurance subsidiary Fidea, the Royal Bank of Scotland which is to sell its highly successful insurance operations, including Direct Line, one of the United Kingdom's leading motor and personal lines insurers, and Dexia, which plans to sell its French life insurance unit.

${ }^{27}$ On the one hand, the bancassurance model as a means of distribution remains strong in other regions, such as France and Spain. French insurer CNP recently formed an alliance with Barclays to sell life insurance in a number of European countries, including Spain and Italy. Furthermore, recent data for 2009 actually indicated a growth in sales via bancassurance. 
150

order to gain from the stronger brand, image and reputation of their banking partners. These reputational assets are now somewhat tarnished and, in any event, the market for typical "bancassurance" products (e.g. savings plans and mortgage or loan-related insurance policies) is stagnant, at least for the time being. Equally, several insurance groups (including Allianz, Europe's largest non-life insurer) have suffered more from problems with their banking subsidiaries than from their core insurance activities, which weakens the case for an insurer retaining or acquiring banking interests. ${ }^{28}$ For all these reasons, many insurers are now likely to focus more closely on traditional insurance business and, like Swiss Re, dispose of or cut down their structured credit and capital markets activities, as well as limiting their involvement with banks.

Finally, we can speculate briefly on how the regulation and supervision of insurance markets might change as a consequence of the crisis. A spate of failures among financial firms always leads for calls for tighter regulation, and this seems inevitable in the case of the banking sector. On the other hand, most senior figures in the insurance industry see no need for wholesale changes in insurance regulation. For example, the Chief Risk Officers of major European insurers have expressed their confidence in the adequacy of the current European project - Solvency II - to ensure that the industry is adequately regulated in the aftermath of the financial crisis ${ }^{29}$ and the U.K. financial regulator, the Financial Services Authority, does not believe that the financial crisis has raised any doubts about the appropriateness of the capital adequacy regime for insurers. ${ }^{30}$ However, the financial crisis has undoubtedly acted as a spur to the speedy implementation of Solvency II. It has also exposed further weakness in the current structure of regulation, allowing appropriate refinements to be built into the new system.

As our analysis shows, the best performing insurers during the financial crisis were those that did not dabble in credit-related instruments, were well capitalised and did not aggressively use softer forms of capital. Therefore in our view, regulators should in the future: (1) limit the use of softer forms of capital; (2) monitor firms' risk appetite; and, (3) create policies that allow small players to flourish. The first of these, at least, can be achieved by increasing the amount of pure equity required on the balance sheet of insurers.

The financial crisis has also signalled a need for action on another, less publicised, issue of regulatory reform in Europe, concerning guarantee funds. These, of course, are funds used to compensate the customers of failed financial firms. They go by a variety of names, depending on the sector concerned, for example deposit guarantee schemes in the case of banks, investment protection schemes for securities and other form of investment and policy-holder protection schemes or insurance guarantee funds for insurers. Development of a European framework with common standards for these funds has been slow and piecemeal, with the main strands (deposits, investments and insurance) remaining largely separate. The issue, at least as far as bank deposits go,

\footnotetext{
${ }^{28}$ Similarly, Fortis has been dismantled following huge losses. In May 2009, it was obliged to sell Fortis Banque-Belgium's number one bank-BNP Paribas.

${ }^{29}$ CRO (2008).

${ }^{30}$ Financial Services Authority (2009).
} 
was thrown into sharp relief recently when customers of many European banks faced, for the first time, the very real prospect of losing their savings in a bank collapse. Differences in levels of deposit protection across Europe led to a flurry of activity, with worried depositors shuffling their money about and governments acting, apparently in panic, to reassure depositors and raise levels of protection in an uncoordinated ad hoc way, sometimes actually discriminating in favour of customers of the worst banks. ${ }^{31}$ This sparked a renewed debate on questions of moral hazard and the distortion of competition in financial services across Europe. To date, there has been only leisurely progress on the creation of a single deposit protection scheme for Europe, but such discussion should surely also take on board the need for some degree of harmonisation in relation to insurance (and investments). Banks, insurers and investment firms offer some competing products and, to the extent that they do, there is clearly a need for harmonisation at EU level across the different sectors of the financial services industry, as well as across Member States.

It seems likely that there will be further regulatory spillovers from the banking and securities sectors into insurance markets as a consequence of the crisis, especially at points where the activities of banks and insurers coincide. In fact, there have already been developments in one such area of overlap. This is the market for CDS, discussed at various points in this paper. Concern at the unregulated nature of this market led New York State to announce its intention to regulate CDS as financial guarantee insurance in those instances where the buyer of the CDS owns the underlying security for which the instrument provides protection. Thus, all buyers who hold or reasonably expect to hold a "material interest" in the reference obligation would need to be licensed as financial guarantee insurers and only financial guarantee insurers would be allowed to issue such CDS. This was intended to ensure that the protection seller has sufficient capital and surplus, and a suitably robust risk management system to protect their buyers. It would prevent firms (such as, in the past, AIG and the monolines) from issuing CDS out of non-insurance subsidiaries. At the time of writing, this initiative has been deferred pending regulatory action on CDS at Federal level.

Finally, we return to a constant theme of this paper, that of systemic risk. It is clear from our analysis that the insurance and banking sectors have become increasingly connected over the last decade. Insurers (particularly life insurers) have extensively participated in the capital markets for additional profitability and risk transfer. This has left insurers exposed to systemic contagion via banks. Insurers have also become significant players in the credit protection market, leaving banks exposed to counterparty risk with potential systemic impact. The key question regarding systemic risk in these two sectors is not the one based on absolute levels - that is, which sector possesses the greater systemic risk - rather there is a need to identify the strength of the systemic link between the sectors as a result of a copula effect between their respective business models. Both banks and insurers have diversified from their traditional set of core activities and have become participants in each other's markets (e.g. insurers in the equity, fund and bond market and banks in insurance-linked securities). The result

\footnotetext{
${ }^{31}$ As when the U.K. Government announced that deposits in the failing Northern Rock bank would be fully protected, a form of largesse that was not explicitly extended to other U.K. banks.
} 
of this diversification is twofold. First, a not insignificant systemic link between banks and insurers has been created. Second, such diversification has changed the business models for both insurers and banks to the point where a return to the traditional (idiosyncratic) models may not be a straightforward task.

\section{References}

Advisen (2008) The Crisis in the Subprime Mortgage Market and the Global Credit Markets: The Impact on E\&O Insurers, Report from http://corner.advisen.com/Subprime_E_O_final_3.pdf.

Aon (2009) 'Quarterly D\&O Pricing Index', Third Quarter 2009 from http://aon.mediaroom.com/index .php? $=63$ \&item $=359$.

Atradius (2009) Press release from http://atradius.hu/corporate/pressreleases/atradiusreports-2008-results .html.

Buhler, W. and Prokopczuk, M. (2007) Systemic risk: Is the banking sector special? Working Paper.

Coface (2009) Press release from http://www.coface.com/CofacePortal/COM_en_EN/pages/home/Who_we are/Press_releases?news $=090309$.

CRO Forum (2008) Comments on the Financial Crisis, from http://www.genevaassociation.org/portals/o/ croforumfinancialcrisisOct $2008 \% 5$ B1\%5D.pdf.

Csiszar, E.N. (2002) 'Systemic risks and the insurance industry', Department of Insurance State of South Carolina, from http://www.oecd.org/dataoecd/29/58/1939448.pdf.

De Nicolo, G. and Kwast, M.L. (2001) Systemic risk and financial consolidation: Are they related? The Federal Reserve Board Financial and Economic Discussion Paper No. 33, Washington DC.

Department for Business Innovation and Skills (2009) from http://www.bis.gov.uk/.

Euler Hermes (2009) Press release from http://www.eulerhermes.com/en/financialnews/financial-news.html.

Financial Services Authority (2004) 'Policy statement 04/16', In Integrated Prudential Sourcebook for Insurers, London: Financial Services Authority.

Financial Services Authority (2009) Financial Risk Outlook 2009, London: Financial Services Authority, from http://www.fsa.gov.uk/pubs/plan/financial_risk_outlook_2009.pdf.

Gropp, R., Vesala, J. and Vulpes, G. (2004) 'Market indicators, bank fragility and indirect market discipline', Federal Reserve Bank of New York Policy Review 10(2): 53-62.

IMF (2009) Global Financial Stability Report, April 2009.

Impavido, G. and Tower, I. (2009) How the financial crisis affects pensions and insurance and why the impacts matter, IMF Working Paper WP/09/151.

Jetuah, D. (2009) Accountancy Age, London, 8 January.

Lacroix, K. (2009) 'The D\&O Diary', from http://www.dandodiary.com/2007/04/articles/securities-litigation/ counting-the-subprime-lender-lawsuits/index.html.

Lloyd's (2008) Directors in the Dock - Is Business Facing a Liability Crisis, Report by Lloyd's of London in association with the Economist Intelligence Unit.

Mutenga, S., Artikis, P.G. and Staikouras, S.K. (2008) 'A practical approach to blend insurance in the banking network', The Journal of Risk Finance 9(2): 106-124.

Parsons, C. and Mutenga, S. (2009) 'Impact of the banking crisis on insurance markets', in G.N. Gregoriou (ed.) The Banking Crisis Handbook, London: Chapman-Hall.

Reuters (2009) 'Bancassurance model seen key to life product sales', from http://uk.reuters.com/article/ idUKLNE56Q05720090727.

Robins, Kaplan, Miller \& Ciresi LLP (RKMC) (2008) 'Credit default swaps: From protection to speculation', from http://www.rkmc.com/Credit-Default-Swaps-From-Protection-To-Speculation.htm.

Swiss Re (2003) Reinsurance-A systemic risk, Sigma No. 5/2003, Swiss Reinsurance Company, Zurich, Switzerland.

Swiss Re (2006) Credit insurance and surety: Solidifying commitments, Sigma No. 6/2006, Swiss Reinsurance Company, Zurich, Switzerland.

Swiss Re (2009) World insurance in 2008, Sigma No. 3/2009, Swiss Reinsurance Company, Zurich, Switzerland. 


\section{About the Authors}

Faisal Baluch is a Fixed Income Analyst at Commerzbank, London.

Stanley Mutenga is Senior Lecturer in Insurance and Risk Management, Cass Business School, City of London.

Chris Parsons is Professor in Insurance, Cass Business School, City of London. 


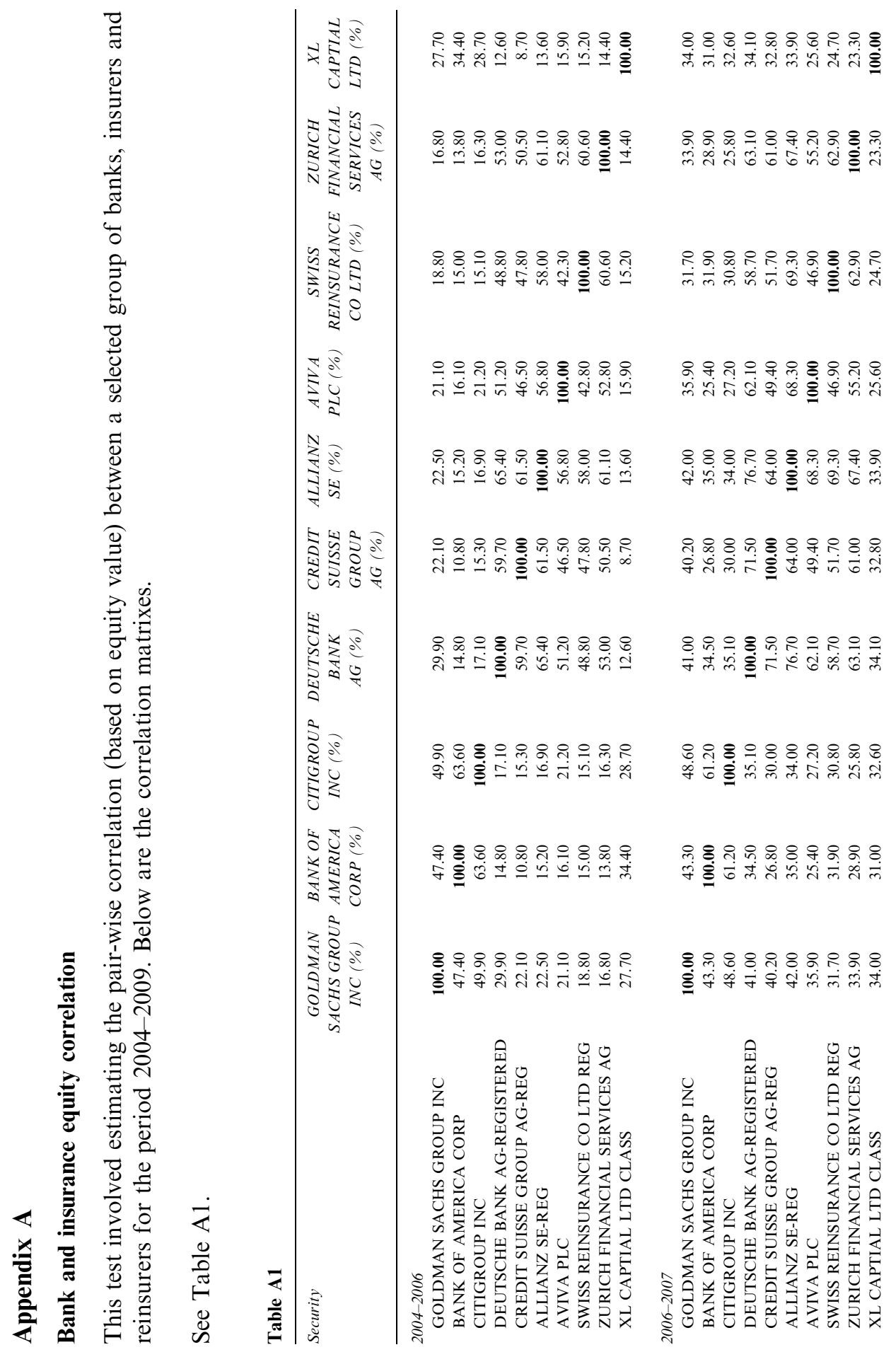




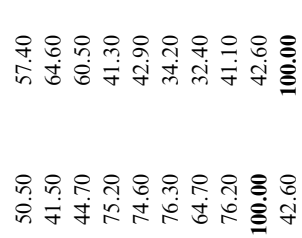

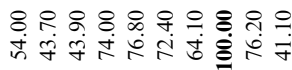

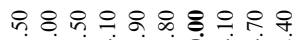

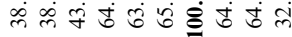

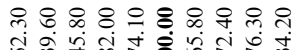

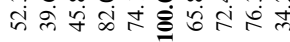

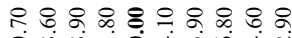

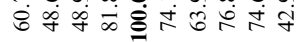

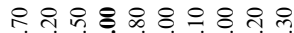

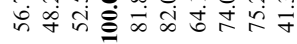

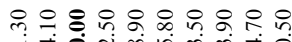

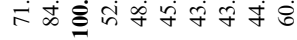

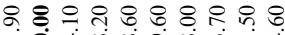

봉

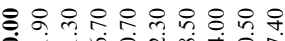

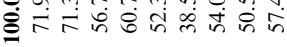

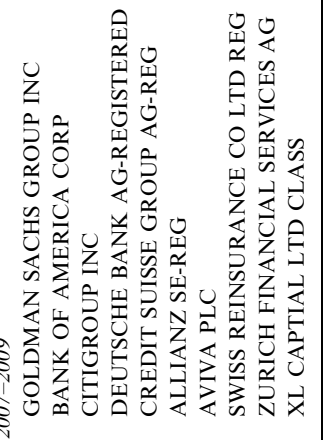




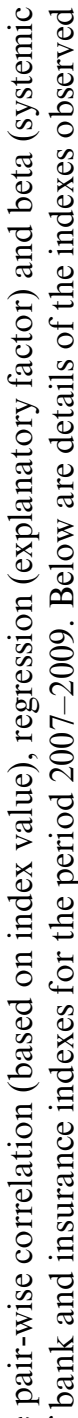

0

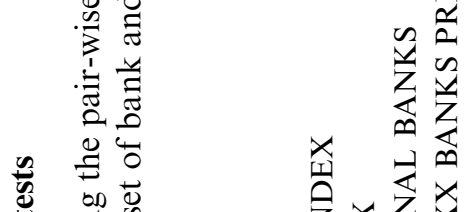

公

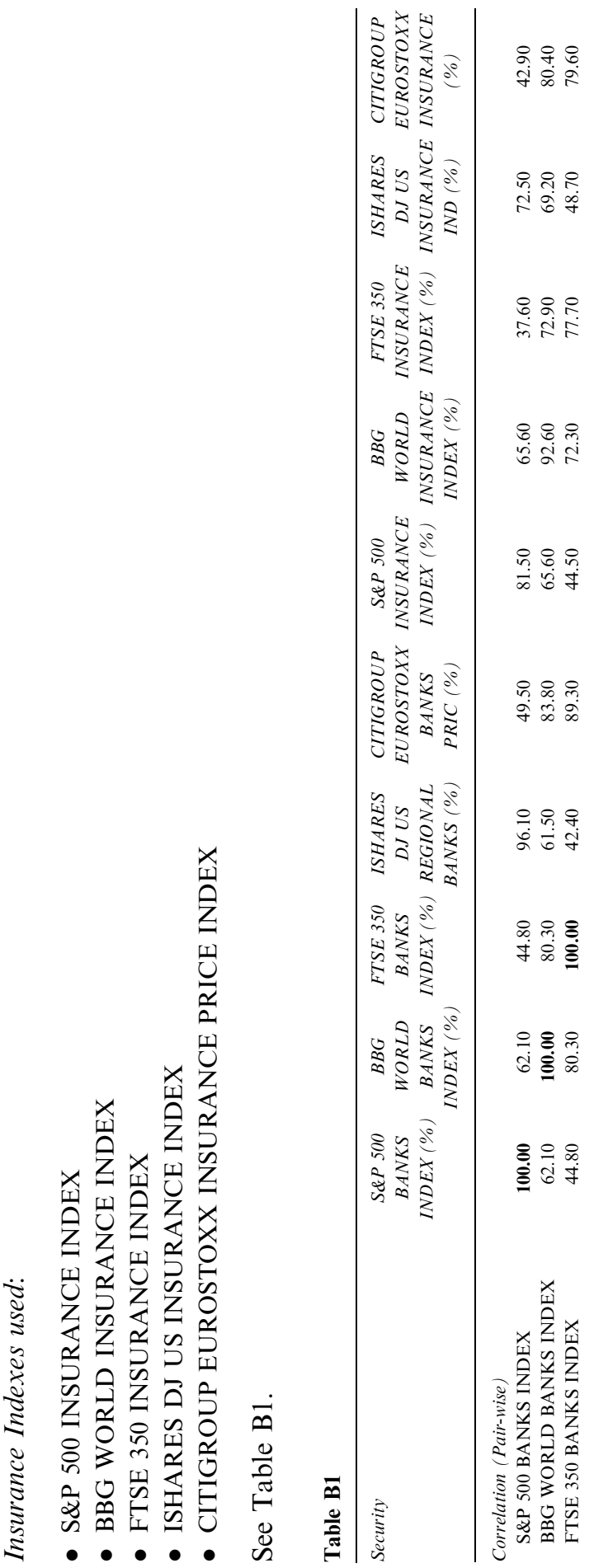

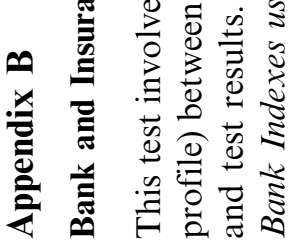

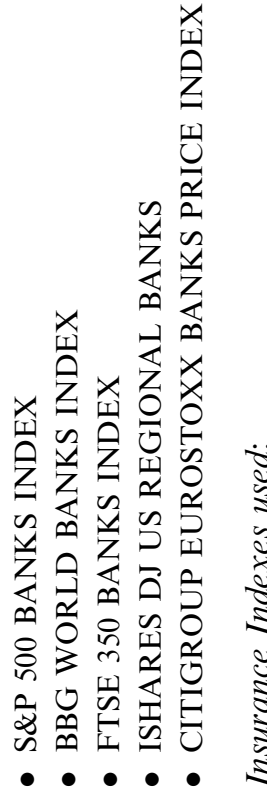

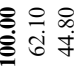


요요 유요요요

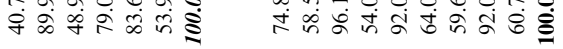

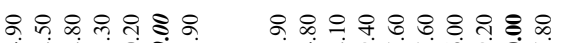

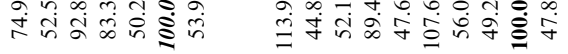

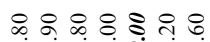

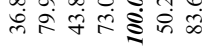

요 8 \& 8 .

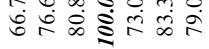

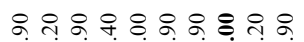

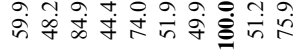

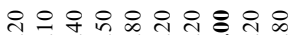

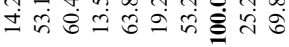

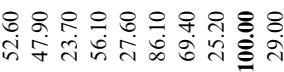

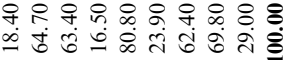

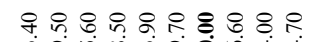

กำ $\$ \circ \& \&$

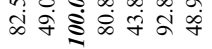

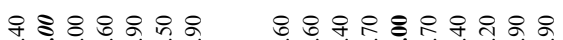

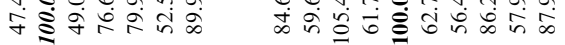

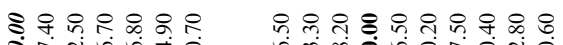

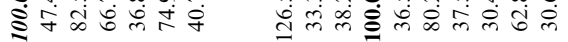

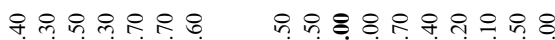

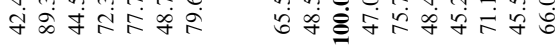

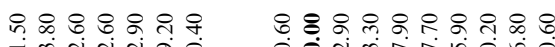

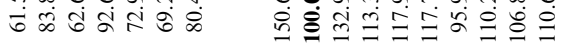

으으요요요요 รัव

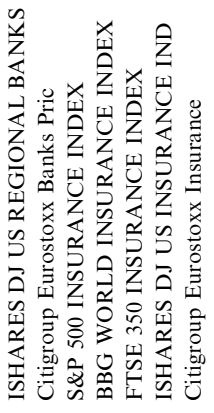

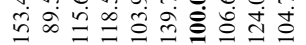

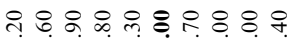

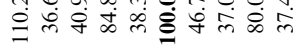

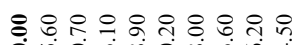

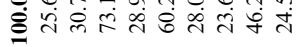

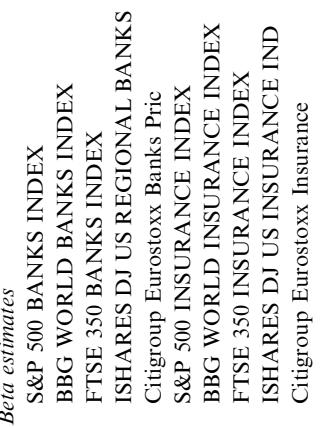

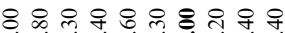
宊

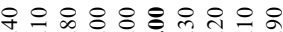

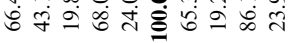

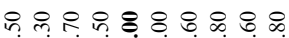

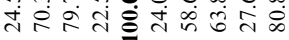

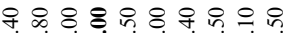
สুต் ฮิ่

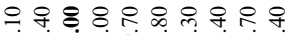
तें

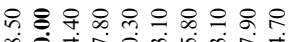

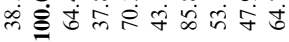

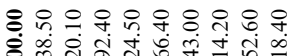

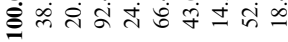

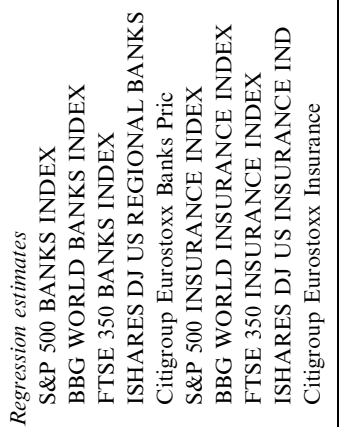




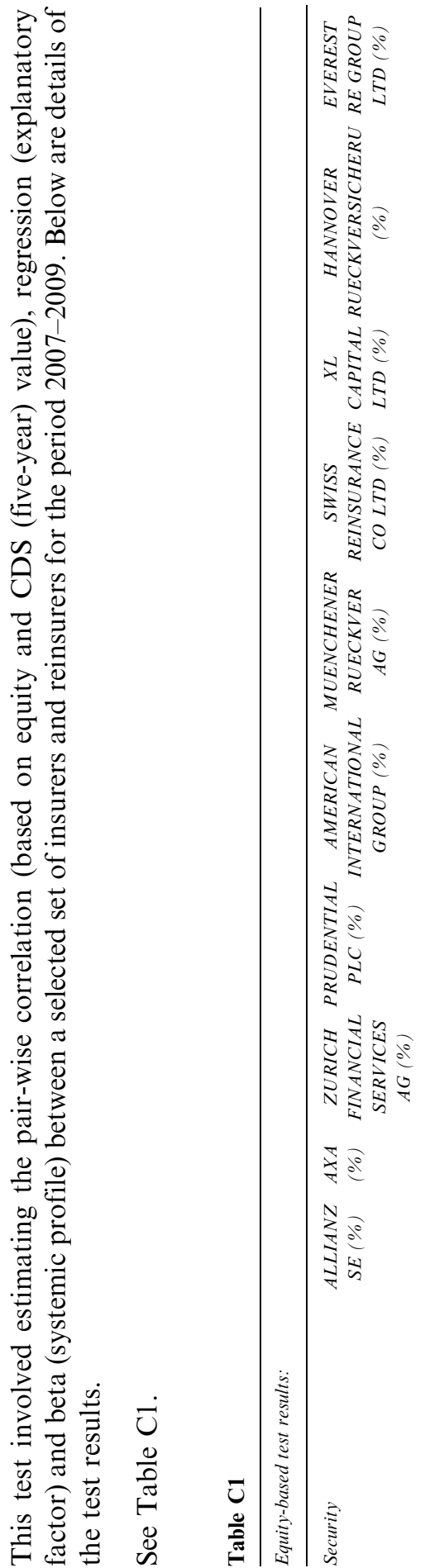

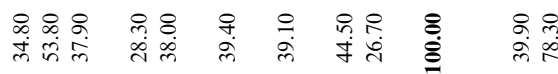

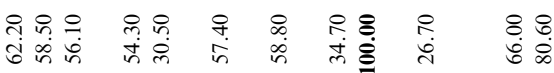

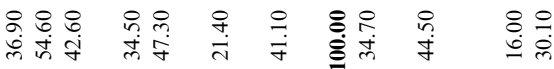

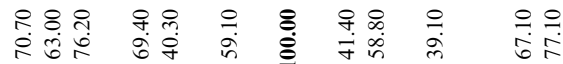

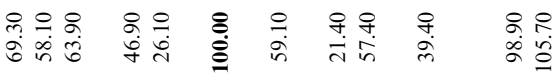

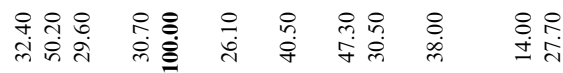

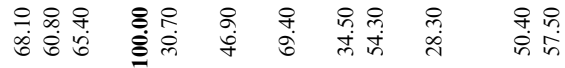

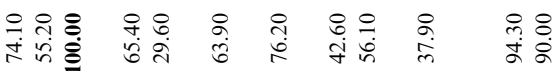

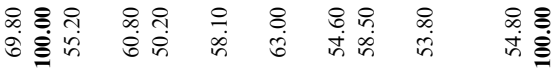

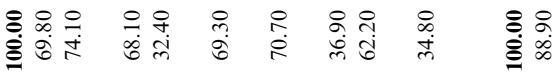

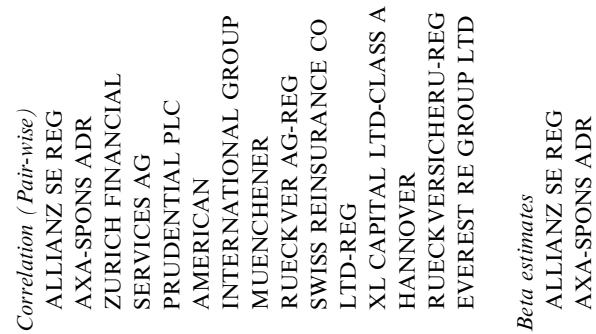




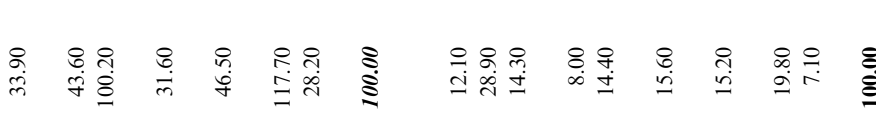

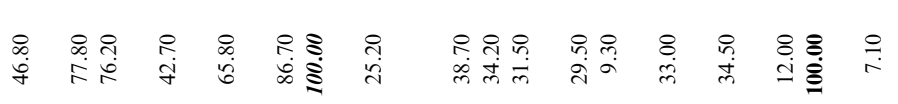

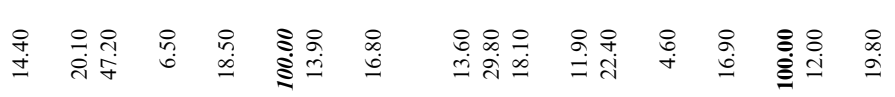

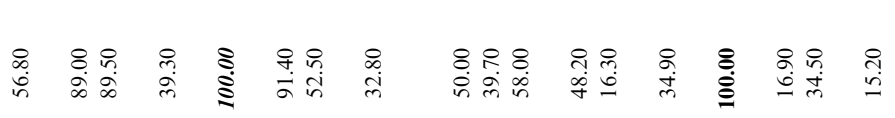

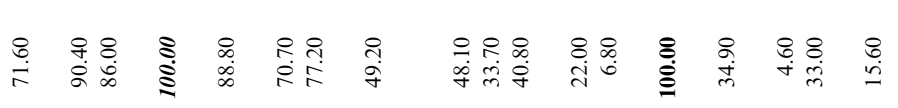

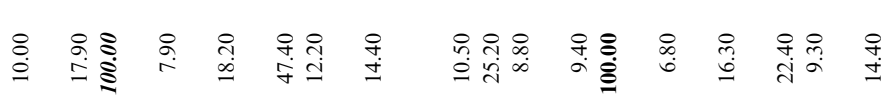

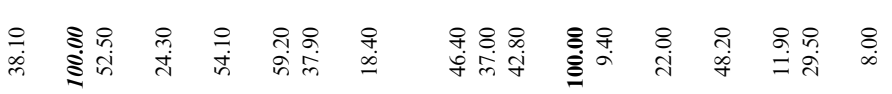

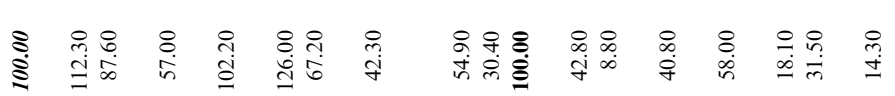

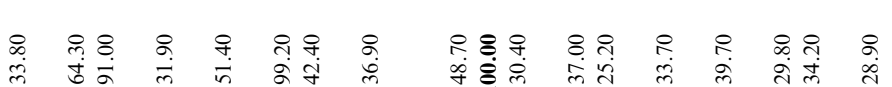

ली ले ले ते

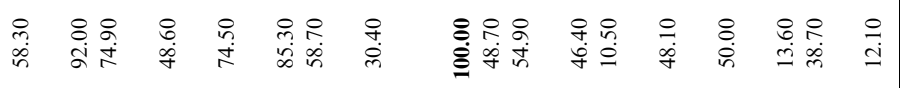

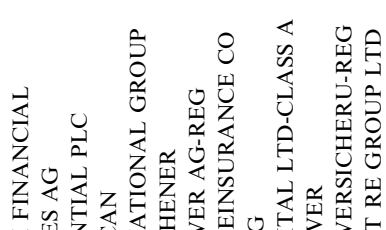

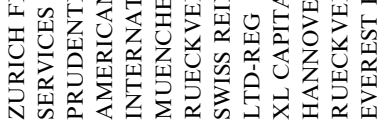

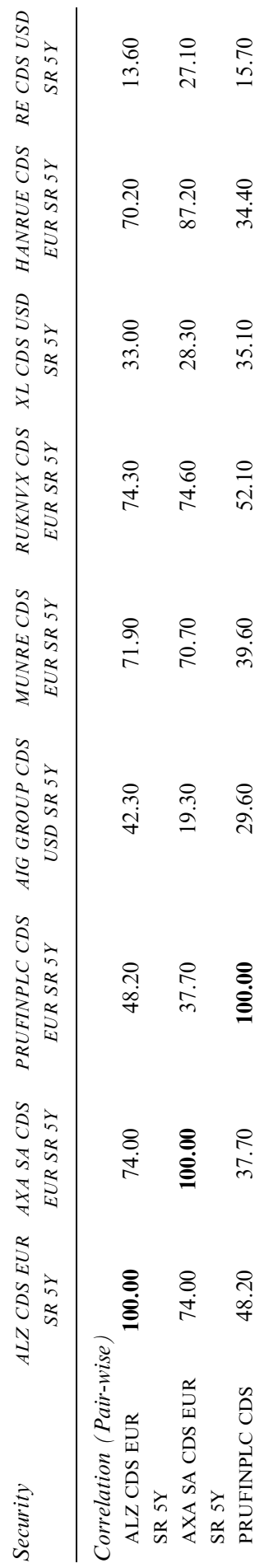




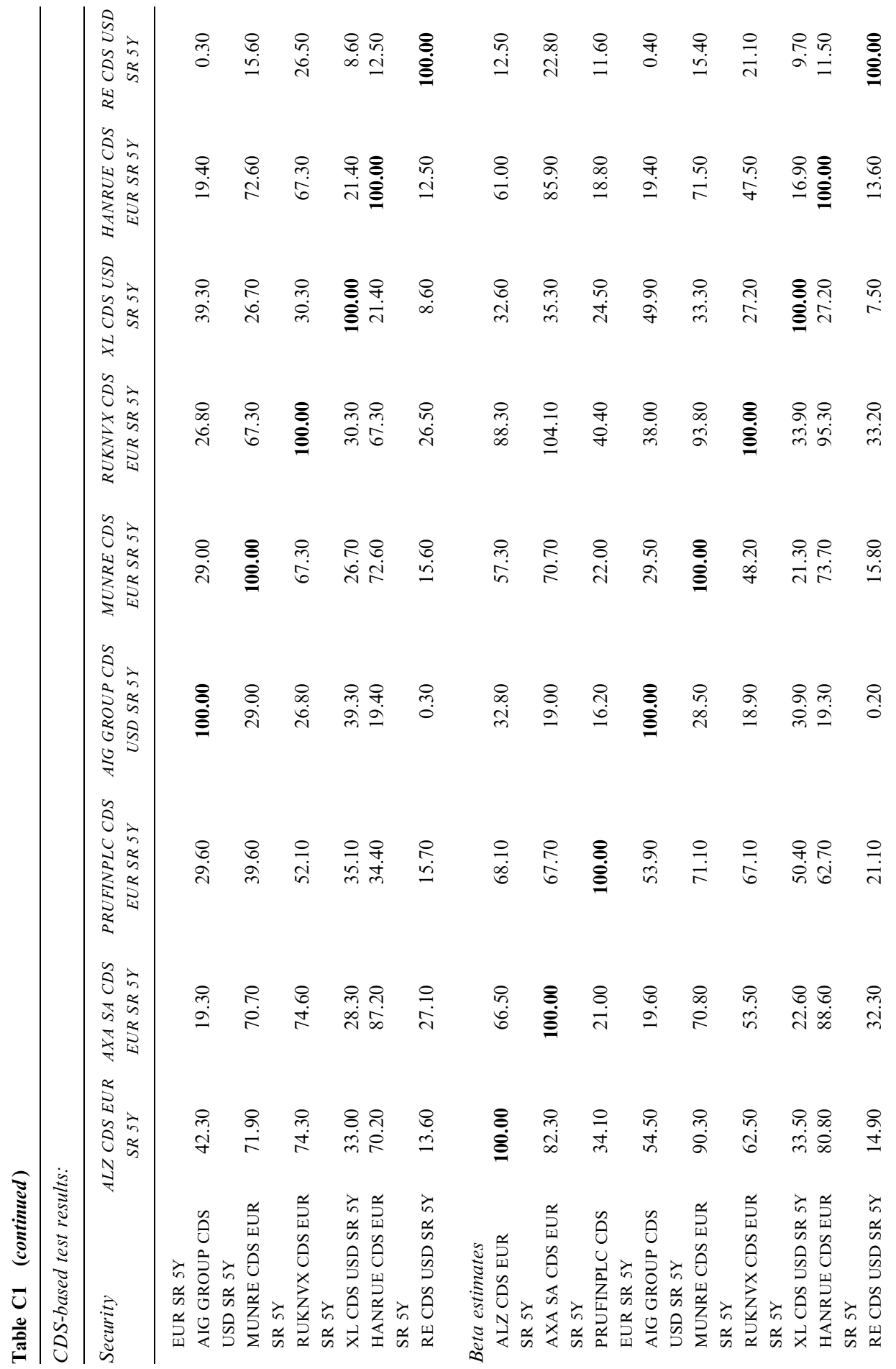




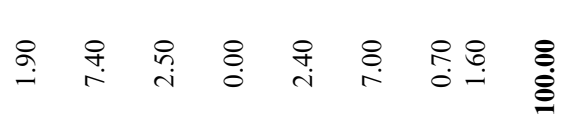

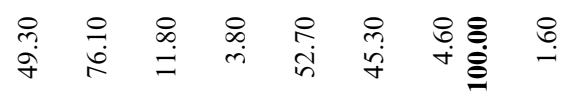

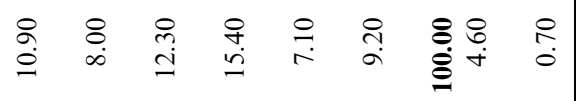

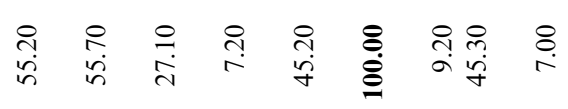

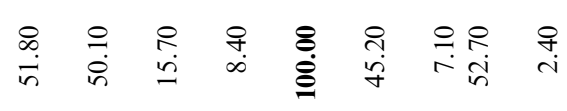

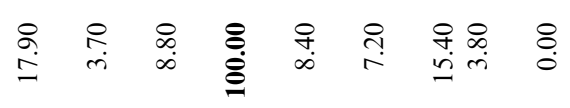

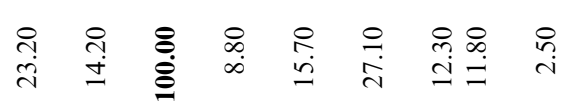

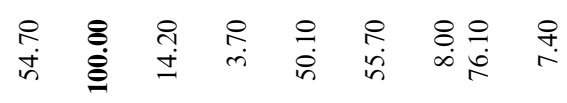

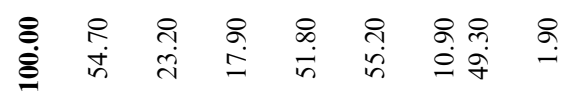

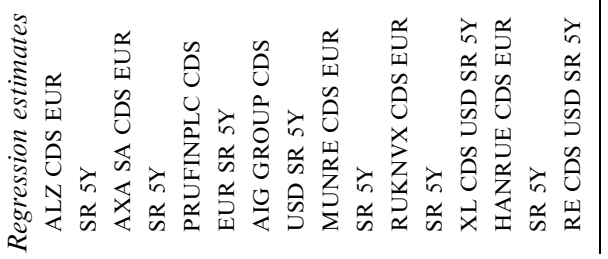




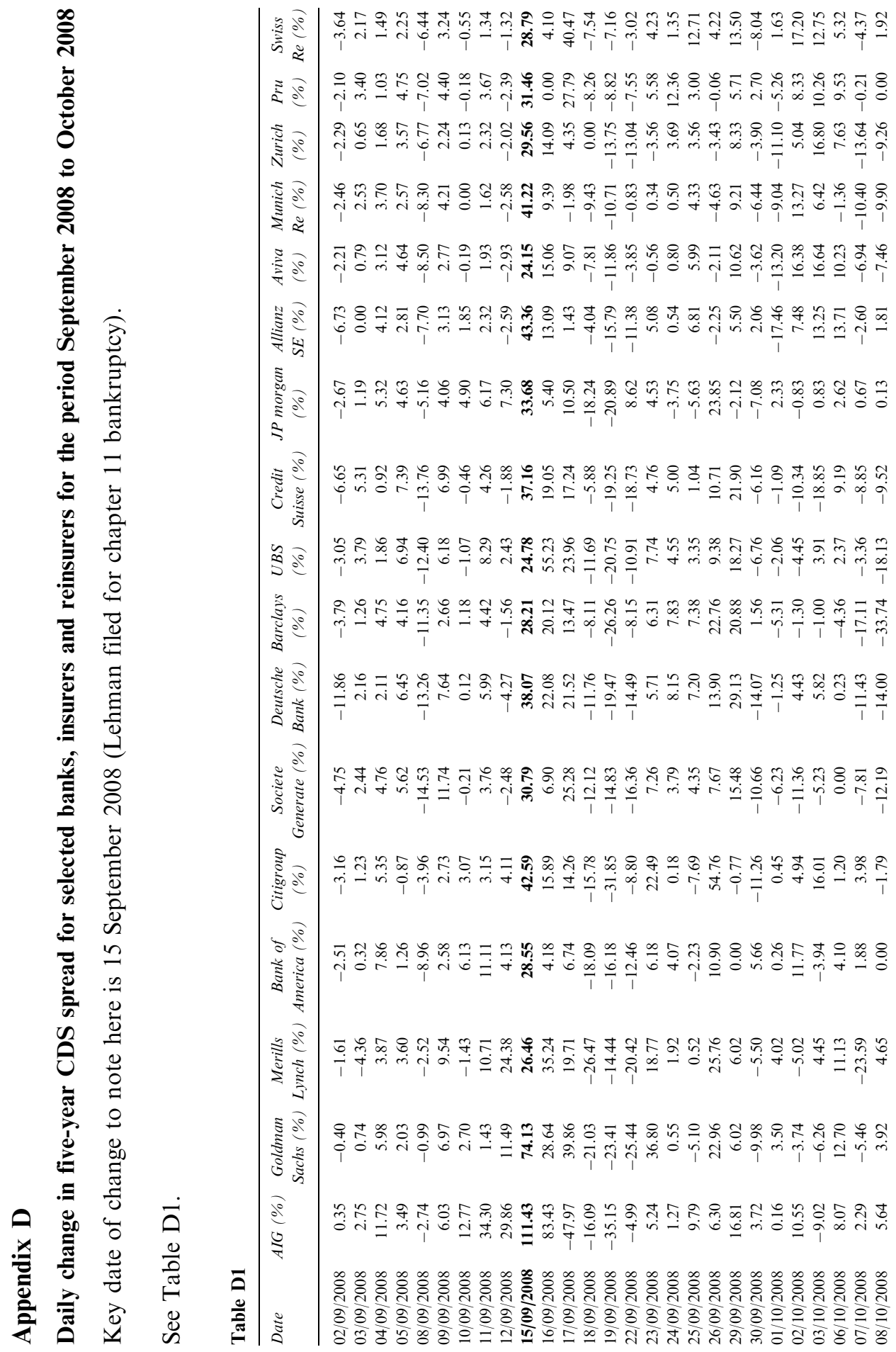




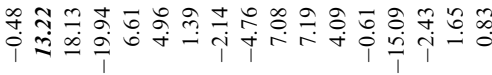
운

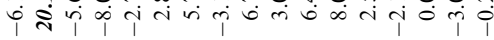

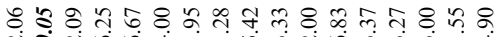
워ํ

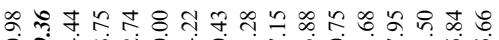

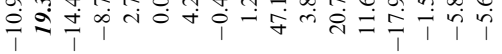

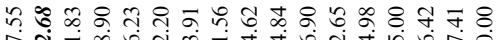

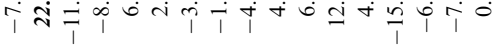

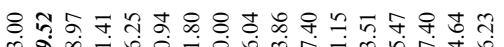

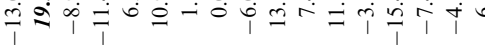

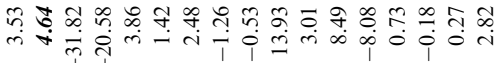

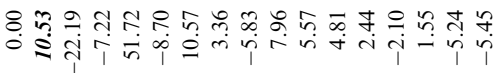

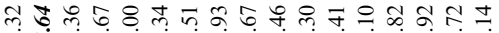

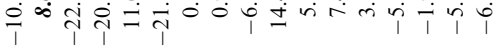

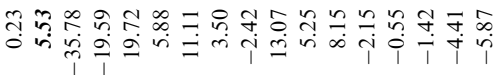

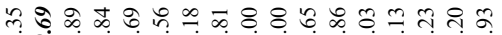
î́

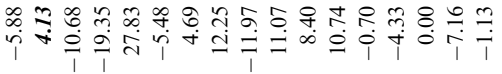

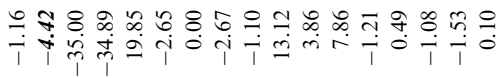
๓

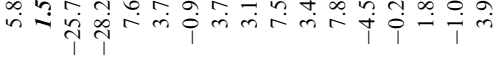

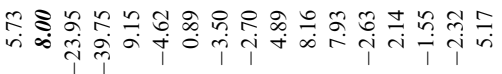

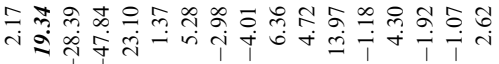

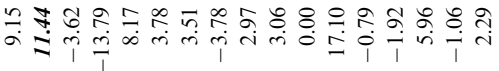

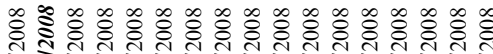

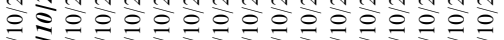

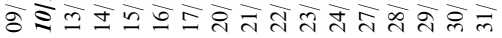

